OPEN ACCESS

Edited by:

Francesca Gilli,

Dartmouth College, United States

Reviewed by:

Bruno Gran,

Nottingham University Hospitals

National Health Service Trust,

United Kingdom

Bert A. 'T Hart,

University Medical Center

Groningen, Netherlands

Andrea Harrer,

Paracelsus Medical University, Austria

Cornelia Bergmann,

Case Western Reserve University, United States

*Correspondence:

Stefanie Kuerten

stefanie.kuerten@ukbonn.de

tThese authors have contributed equally to this work

Specialty section: This article was submitted to

Multiple Sclerosis and

Neuroimmunology,

a section of the journal

Frontiers in Neurology

Received: 05 August 2020 Accepted: 05 October 2020 Published: 03 November 2020

Citation:

Chunder R, Schropp V and Kuerten S

(2020) B Cells in Multiple Sclerosis and Virus-Induced Neuroinflammation.

Front. Neurol. 11:591894.

doi: 10.3389/fneur.2020.591894

\section{B Cells in Multiple Sclerosis and Virus-Induced Neuroinflammation}

\author{
Rittika Chunder ${ }^{\dagger}$, Verena Schropp ${ }^{\dagger}$ and Stefanie Kuerten* \\ Institute of Anatomy and Cell Biology, Friedrich-Alexander University Erlangen-Nuremberg, Erlangen, Germany
}

Neuroinflammation can be defined as an inflammatory response within the central nervous system (CNS) mediated by a complex crosstalk between CNS-resident and infiltrating immune cells from the periphery. Triggers for neuroinflammation not only include pathogens, trauma and toxic metabolites, but also autoimmune diseases such as neuromyelitis optica spectrum disorders and multiple sclerosis (MS) where the inflammatory response is recognized as a disease-escalating factor. B cells are not considered as the first responders of neuroinflammation, yet they have recently gained focus as a key component involved in the disease pathogenesis of several neuroinflammatory disorders like MS. Traditionally, the prime focus of the role of $\mathrm{B}$ cells in any disease, including neuroinflammatory diseases, was their ability to produce antibodies. While that may indeed be an important contribution of B cells in mediating disease pathogenesis, several lines of recent evidence indicate that B cells are multifunctional players during an inflammatory response, including their ability to present antigens and produce an array of cytokines. Moreover, interaction between B cells and other cellular components of the immune system or nervous system can either promote or dampen neuroinflammation depending on the disease. Given that the interest in B cells in neuroinflammation is relatively new, the precise roles that they play in the pathophysiology and progression of different neuroinflammatory disorders have not yet been well-elucidated. Furthermore, the possibility that they might change their function during the course of neuroinflammation adds another level of complexity and the puzzle remains incomplete. Indeed, advancing our knowledge on the role of B cells in neuroinflammation would also allow us to tackle these disorders better. Here, we review the available literature to explore the relationship between autoimmune and infectious neuroinflammation with a focus on the involvement of B cells in MS and viral infections of the CNS.

Keywords: B cells, multiple sclerosis, neuroinflammation, central nervous system, viral infection, EBV

\section{INTRODUCTION}

Historically, the primary focus of B cells as enhancers of autoimmunity was their exclusive ability to differentiate into plasma cells and produce autoantibodies. Over the last few decades our understanding that B cells are merely responsible for the production of autoantibodies has been challenged and antibody independent effector functions of B cells are now greatly appreciated (1-8). Based on preclinical and clinical data, mounting evidences suggest that B cells effectively collaborate with $\mathrm{T}$ cells to initiate and fine-tune $\mathrm{T}$ cell-dependent responses 
in the development of several autoimmune diseases (9-11). B cells are also known to act as negative sensors of autoimmunity that regulate immunological functions by suppressing $\mathrm{T}$ cell proliferation, secreting anti-inflammatory cytokines $(12,13)$ and controlling monocyte activity (14-18). Consequently, B cells have now emerged to take center stage as cells with effector as well as immunoregulatory potential.

Indeed, a large volume of literature emphasizes on the heterogenous roles of $\mathrm{B}$ cells in autoimmunity and peripheral inflammation, yet our understanding of the extent of $\mathrm{B}$ cell involvement in autoimmune neuroinflammation remains incomplete.

Neuroinflammation can be defined as a coordinated and complex interaction between CNS-resident cells and the peripheral immune system and is characterized by a host of cellular and molecular changes within the CNS $(19,20)$. Neuroinflammation is a prominent feature in the etiology of a number of neurological disorders and diseases including multiple sclerosis (MS), and viral encephalitis (21) where the inflammatory response is generally recognized as a disease-escalating factor $(22,23)$. A common denominator for neuroinflammatory disorders is the impairment of the integrity of the endothelial, epithelial, and glial brain barriers that together compartmentalize the CNS from the periphery (24-26).

Cells of the innate immune system are typically the focal point for any discussion of neuroinflammation $(19,27)$, while B cells are not considered as the first responders of an inflammatory insult within the CNS. However, recent evidence suggests that $\mathrm{B}$ cells, which are largely absent in the CNS parenchyma or sparsely present in the cerebrospinal fluid (CSF) of healthy individuals $(27)$, rapidly accumulate in the $\operatorname{CSF}(28,29)$ during neuroinflammation and their numbers increase by several folds in the CNS parenchyma or the perivascular spaces (30).

Taken together, it is only recently that the importance of B cells as multifunctional players in neuroinflammatory disorders is being acknowledged with several outstanding questions requiring elucidation (31-33).

In this article, we discuss the literature available on how B cells are involved in two different instances of neuroinflammation by highlighting their beneficial and detrimental roles in ameliorating or aggravating disease pathophysiology, respectively. On the one hand, we focus on MS, which is a classical example of autoimmune neuroinflammation and on the other hand we extend our discussion by drawing parallels between MS and virus-induced neuroinflammation with respect to the involvement of B cells.

\section{GENERAL INTRODUCTION TO B CELL BIOLOGY}

As B cells are in the focus of this review, this chapter will briefly summarize the principles of B cell biology as well as provide an overview of different $B$ cell subsets and their main functions. B cells belong to the population of lymphocytes and they are part of the adaptive immune system. They express clonally diverse antigen recognition molecules known as immunoglobulins (Igs). Membranebound Ig on the surface of $\mathrm{B}$ cells acts as a receptor, the so-called $\mathrm{B}$ cell receptor (BCR), that recognizes specific antigenic epitopes.

Very briefly, the development and differentiation of a $\mathrm{B}$ cell begins in the bone marrow from a pro- $\mathrm{B}$ cell to an immature naïve B cell $(34,35)$. At this stage of development, $\mathrm{B}$ cells undergo various checkpoints including clonal deletion and receptor editing, which prevents the development of autoreactive cells (36-38). B cells that successfully complete these checkpoints leave the bone marrow as transitional B cells (39). However, the checkpoints can be imperfect and B cells capable of self-directed autoimmune responses are common and exist as a part of the healthy immune repertoire $(40,41)$. An immature naïve $\mathrm{B}$ cell migrates into a secondary lymphoid organ where it then develops into a mature naïve $B$ cell, expressing a BCR with single antigenic specificity (42). A mature naïve B cell can generally be divided into three further subsets: B-1 B cells, marginal zone (MZ) B cells and follicular B cells, with the B$1 \mathrm{~B}$ cells being further subdivided into $\mathrm{B}-1 \mathrm{a}\left(\mathrm{CD} 4^{+}\right.$helper $\mathrm{T}$ cell-dependent) and $\mathrm{B}-1 \mathrm{~b}\left(\mathrm{CD} 4^{+}\right.$helper $\mathrm{T}$ cell-independent) B cells (43). B-1a cells provide protection against bacterial infections while B-1b cells function independently of $\mathrm{T}$ helper cells and provide adaptive immune response to polysaccharides, for instance lipopolysaccharide, and other $\mathrm{T}$ cell-independent antigens (44). When mature naïve B cells encounter their cognate antigen in the secondary lymphoid tissue, they become activated. While the primary signal for B cell activation is the binding of antigen to its antigen-specific receptor expressed by the B cell, secondary signals are also required. A B cell response to the antigen is successful only by the synergy between the engagement of their BCR and co-receptors like Toll-like receptors (TLRs) and CD40, which control class switching and affinity maturation in these activated B cells $(45,46)$. Following activation, some of these B cells-in conjunction with $\mathrm{CD} 4^{+} \mathrm{T}$ cell help-take part in germinal center (GC) reactions within the lymphoid follicles.

Lymphoid follicles in secondary lymphoid tissue act as a site of antigen-induced B cell proliferation and they have a complex microenvironment, which consists of immune cells, adhesion molecules and antigen-antibody complexes. GCs are specialized areas within these lymphoid follicles where B cells undergo somatic hypermutation leading to affinity maturation to eventually develop into memory B cells or antibody secreting plasma cells $(47,48)$. The adaptive immune system can evoke an enhanced response to a previously experienced pathogen. This response depends on memory lymphocyte populations of which memory $\mathrm{B}$ cells are a part. The improved responsiveness of memory $\mathrm{B}$ cells is attributed to class switching and high affinity BCR on their surface which they develop within the GC. However, it is important to note that memory B cells are a heterogenous population and can be further differentiated into $\mathrm{T}$ cell-dependent/GC-dependent memory $\mathrm{B}$ cells or GC-independent memory B cells (49). 


\section{AUTOIMMUNE NEUROINFLAMMATION: A FOCUS ON MULTIPLE SCLEROSIS (MS)}

\section{An Overview of the Disease}

MS is a neuroinflammatory demyelinating disorder of the CNS in genetically predisposed individuals (50). MS is considered to be a heterogenous disease with different clinical courses depending on the subtype (51). While $\sim 85-90 \%$ of MS patients present with a relapsing-remitting form of MS (RRMS), most of these patients develop secondary progressive disability (SPMS) in the course of the disease. The rarer form of MS is primary progressive MS (PPMS) which has an insidious disease onset and is characterized by a steady increase in neurological disability (52). The pathogenic role of inflammation in all the subtypes of MS remains undisputed (53-55), and the inflammatory reaction in $\mathrm{MS}$ is said to be a cumulative effect of a number of factors including cells of the innate and adaptive immune system, their mediators and effector molecules like cytokines and antibodies (56-58).

\section{Evidence of B Cells in MS}

Despite historically being dubbed as a "T-cell mediated disease," emerging evidence suggests that B cells contribute to MS pathogenesis in more than one way (59-62). The multifaceted roles of B cells as "shapers" in MS disease progression include antibody production, pro- and anti-inflammatory cytokine secretion and antigen presentation $(32,63,64)$.

One of the earliest indications that $\mathrm{B}$ cells contribute to disease pathogenesis comes from the identification of persistent oligoclonal bands (OCBs) in the CSF of $>90 \%$ of all patients diagnosed with clinically definite MS $(65,66)$. In general, the presence of OCBs suggests abnormal intrathecal production of clonally expanded IgGs which is an indication of the pathogenic role of $\mathrm{B}$ cells in neuroinflammatory and infectious diseases of the CNS (67). In MS, a direct link between CSF-infiltrating $\mathrm{B}$ cells as the source of Igs associated with these OCBs has been established (68). Two studies have demonstrated that a significantly increased accumulation of B cells in the CSF of MS patients strongly correlates with intrathecal synthesis of IgG $(69,70)$. Furthermore, these B cells have been characterized to be of the $\mathrm{IgM}^{-} \mathrm{IgD}^{-}$class-switched memory and plasmablast phenotypes. In line with the findings above, other studies have separately identified that clonally expanded B cells in the CSF of MS patients show evidence of somatic hypermutation and affinity maturation $(71,72)$. Indeed, the presence of $\mathrm{B}$ cells is not just restricted to the CSF but overlapping B cell populations are common between the periphery and the different CNS compartments $(58,73,74)$ providing proof that clonally related B cells participate in bidirectional exchange across the brain barriers in the case of MS. In another study Ig gene repertoire sequencing of CSF and peripheral blood B cells in treatmentnaïve MS patients has also revealed a clonal relationship between the B cell populations in the two compartments (75).

The involvement of both B cells and autoantibodies in MS also comes from neuropathological analysis of lesions from patients. For instance, one of the most frequent patterns in MS lesions is characterized by antibody deposition and complement activation (76). Although the presence of complement supports a pathogenic role of the antibodies in correlation with areas of demyelination $(76,77)$, the antigenic targets for these autoantibodies remain unclear. Moving from the detection of antibodies to B cells in autopsied CNS tissue from MS patients, immunohistochemical stainings have indicated the accumulation of B cells and plasma cells in perivascular spaces of the brain which are associated with active demyelination (78). A more recent study has revealed a prominent presence of $\mathrm{CD} 20^{+} \mathrm{B}$ cells in the lesions of patients with acute MS (79), indicating that B cells may be important in the overall inflammatory process and also in the early stages of the MS.

Furthermore, in the secondary progressive stages of MS, lymphoid-like B cell follicles have been detected in the inflamed meninges of up to $40 \%$ of patients (80-82). These ectopic follicles containing a complex network of B- and T cells, plasma cells as well as follicular dendritic cells (83) are preferentially localized within the subarachnoid space, attached to the pial membrane and their presence is often associated with a more aggressive disease progression $(60,81)$. A connection between the presence of these meningeal $\mathrm{B}$ cell follicular aggregates and the sustenance of $B$ cell maturation locally within the CNS leading to a compartmentalized humoral immune response has been made (61). In addition to these ectopic B cell follicles in the leptomeninges of SPMS patients, meningeal $\mathrm{CD}^{+} 0^{+} \mathrm{B}$ cell infiltrates have also been reported in patients with PPMS which correlate with a higher degree of cortical demyelination (84). However, as yet there is little knowledge on the (immuno)phenotype of these B cells, their molecular characteristics or the precise role they play within these follicular structures or aggregates. Of importance are the difficulties faced in studying these aggregates because of limited availability of appropriate B cell follicle containing tissue, poor quality of tissue and technical difficulties of detecting these follicles due to the easy detachment of the meninges during autopsy (85).

A number of antigen experienced B cell clones have also been detected within the CNS parenchyma in MS patients with a chronic progressive or secondary progressive disease course (86). Furthermore, a more recent study demonstrated the presence of B cell follicles in the spinal meninges of SPMS patients that were associated with demyelination and axonal loss (87). These findings suggest that B cells are probably not just localized in the extraparenchymal tissue of the brain but also populate different areas of the CNS tissue, including the spinal cord.

Despite there being little doubt regarding the presence of $\mathrm{B}$ cells in the different compartments of MS patients, the precise site(s) or trigger(s) of B cell activation remain fairly speculative $(31,63)$. One hypothesis for their activation could be that B cells encounter their cognate antigen in the peripheral deep cervical lymph nodes-which is the site of CSF-mediated drainage of brain antigens-where they differentiate into memory B cells or plasmablasts before migrating into the CNS (31). In the inflamed CNS, these plasmablasts or memory B cells may further differentiate into plasma cells. This differentiation may be even in the absence of specific antigens but rather in an antigen non-specific manner by a polyclonal stimulus (88). For example, human herpesvirus 6 (HHV-6), which is an infectious 
agent implicated in the pathogenesis of MS, may be involved in polyspecific $\mathrm{B}$ cell activation $(89,90)$. One of the obvious manifestations of these antibody secreting plasma cells within the CNS is in the form of OCBs as seen in the CSF of MS patients. It may also be plausible that naive B cells enter the CNS and are activated within the CNS (for example, by taking part in GC reactions within meningeal $B$ cell follicles) and complete the circle of eventually differentiating into plasma cells.

To summarize, the studies mentioned above indicate that the number of $\mathrm{B}$ cells and their location possibly depends on the disease course and duration, with a substantial amount of variation between individual cases. It supports more careful screening of autopsied CNS tissue from MS patients with a chronic disease course with the purpose of characterizing the $\mathrm{B}$ cells beyond their CD20 marker. The literature strongly suggests that B cells are involved in MS and are present in all the different compartments within the CNS and in the periphery. Yet, in what ways these B cells establish themselves in the inflamed brain, where and how they are activated has not yet been clearly elucidated with only a limited number of studies addressing these questions (91-93).

\section{Role of B Cells in MS}

The importance of different antibody-independent functions of $\mathrm{B}$ cells in the pathogenesis of MS is highlighted by the success story of treatment with monoclonal anti-CD20 antibodies. It has been shown that depletion of circulating $B$ cells by the chimeric antiCD20 monoclonal antibody rituximab effectively led to rapid reduction in gadolinium (Gd)-enhancing lesions and MRI lesion load as well as relapse activity in RRMS patients $(94,95)$. This anti-CD20 monoclonal antibody has also shown high efficacy in the removal of $\mathrm{CD} 20^{+} \mathrm{B}$ cells from the peripheral and CSF compartments $(96,97)$. However, the reduction of $\mathrm{B}$ cells in the CSF was comparatively much lower than in the periphery $(30,98,99)$. Ocrelizumab, a humanized anti-CD20 antibody, has demonstrated high efficacy in reducing relapse rates in RRMS patients in different clinical trials and is also associated with lower rates of clinical and MRI progression in patients with progressive MS (100, 101).

Since plasma cells do not express CD20, they are not directly depleted by anti-CD20 therapy (96). Therefore, the decrease in disease activity following treatment of MS patients with antiCD20 antibodies is possibly linked to one or more antibodyindependent functions of B cells such as antigen presentation (to T cells) or cytokine production (32).

$\mathrm{B}$ cells can function as effective antigen presenting cells (APCs) when they recognize the same antigen as T cells (102), which is important for the activation of effector T cells (103). As a part of this B- and T- cell cognate interactions, the combination of co-stimulatory signals plays a key role in defining the $\mathrm{T}$ cell response of which the interaction between CD80/CD86 and CD28 is among the best characterized (32). One such antigen presenting potential of B cells in the context of MS comes from reports indicating that during MS disease exacerbations, the number of $\mathrm{CD}^{+} 0^{+} \mathrm{B}$ cells abnormally increases $(59,63,104)$. Exactly what set of triggers is responsible for this upregulation of CD80 in B cells of MS patients is, however, less known. One of the possibilities is that interferon (IFN)- $\beta$ induces CD80 expression $(104,105)$, which is a cytokine produced by innate immune cells like macrophages and non-immune cells like fibroblasts and epithelial cells. It has been shown that IFN- $\beta$ therapy noticeably reduces the number of circulating CD80 B cells $(59,104)$ in MS patients. Secondly, ligands for TLR $1 / 2,4,7 / 8$ are also known to induce a strong activation of B cells and upregulation of CD40 and CD80 (106). In the context of MS, TLRs indeed play a major role in the initiation of disease as well as in the triggering of relapses $(107,108)$. Furthermore, a variety of cytokines like IL4 and IL-2 that are relevant in the context of MS, are also known to induce CD80 expression on B cells (109).

The potential of memory B cells from RRMS patients to activate $\mathrm{T}$ cells has also been demonstrated by Jelcic et al. and Harp et al. $(110,111)$, where T helper cells promoted $\mathrm{B}$ cell proliferation and differentiation, thus establishing a bidirectional B- and $\mathrm{T}$ cell interaction that plays a key role in MS pathogenesis (110).

Furthermore, circulating B cells of untreated MS patients exhibit an abnormal balance of pro- to anti-inflammatory cytokine responses (112-114). These abnormalities in the effector-cytokine production by MS B cells in turn also affects the myeloid as well as the $\mathrm{T}$ cell compartments. Of note, in vitro studies using B cells from MS patients demonstrate the ability of granulocyte-macrophage colony-stimulating factor (GM-CSF) expressing $\mathrm{B}$ cells to efficiently enhance myeloid cell proinflammatory responses in a GM-CSF dependent manner (115). Another example comes from anti-CD20 depletion studies where changes in the number of pro-inflammatory B cells correlated with a persistent decrease of $\mathrm{T}$ cell lineage pro-inflammatory responses (116). These studies have demonstrated that $\mathrm{B}$ cells from MS patients in comparison to healthy controls cannot only produce a myriad of pro-inflammatory cytokines $(114,115)$, but these cytokines also have the ability to modify responses of other immune cell populations $(115,117)$.

As mentioned earlier, cortical demyelination in a subgroup of MS patients is associated with ectopic B cell follicles in the meninges which implies that B cells may be involved in cortical injury by secreting cytotoxic factors (63). In vitro studies using B cells from RRMS patients substantiate that they are capable of killing oligodendrocytes and neurons in an antibodyindependent manner involving apoptosis $(118,119)$, while the identity of the cytotoxic products remains to be clarified.

However, it may also be necessary to note that the beneficial effects of anti-CD20 therapy in MS patients cannot solely be attributed to the depletion of $\mathrm{B}$ cells but rather $\mathrm{CD} 20^{+} \mathrm{T}$ cells may also be targeted (120). Although CD20 is a hallmark cell surface marker of $\mathrm{B}$ cells, a proportion of $\mathrm{CD}^{+} \mathrm{T}$ cells also expresses this marker (121) which are found in an increased number in the peripheral blood and CSF of MS patients (122). While it has been proposed that $\mathrm{T}$ cells present in the blood may acquire CD20 from $\mathrm{B}$ cells by a process called trogocytosis and are therefore $\mathrm{CD}^{+} \mathrm{CD}_{2}{ }^{+}$, Schuh et al. have elaborately demonstrated that indeed a subset of $\mathrm{T}$ cells transcribes CD20 but no other molecules typically found on B cells (120). CD20 expressing $\mathrm{T}$ cells have been reported to be a highly activated pro-inflammatory cytokine-producing cell population 
with pathogenic potential $(120,121)$. Furthermore, several studies have elaborately demonstrated that this population of $\mathrm{CD} 20^{+} \mathrm{T}$ cells can be effectively depleted by rituximab and ocrelizumab in patients with RRMS (122-124) suggesting that depletion of this cell population might be an important consideration in the overall clinical effectiveness of anti-CD20 directed therapies (125).

\section{Animal Model(s) of MS: Experimental Autoimmune Encephalomyelitis (EAE)}

There are of course limitations of studying the pathomechanisms of disease development in human subjects. Scientists have therefore turned to using EAE, which is one of the best characterized and most frequently used animal models for studying neuroinflammation in the human disease MS. A wide range of EAE models have been induced in a number of different species (including rats, mice, and primates) with varying degrees of efficacy to study different aspects of MS pathogenesis (126129). Yet, most of these models are biased towards a CD4 ${ }^{+}$ $\mathrm{T}$ cell-restricted immune response and no single experimental model covers all the immunological and pathological features of the human disease $(130,131)$. In particular, some aspects of MS, especially the progressive stage of MS, have so far been poorly covered in commonly used experimental rodent models.

As discussed above, there is a growing appreciation of the involvement of B cells in the later stage of MS where aggregates of B cells have been found in the leptomeninges of SPMS patients $(81,83)$. These B cell aggregates feature a complex follicle-like structure and are most likely instrumental in strong meningeal inflammation. Modeling this B cell aspect of the human disease in the conventional EAE models has yielded varying results between the different strains of rodents and with regard to the immunizing antigen $(s)(85,132)$.

One of the more robust mouse models that is both B celland antibody-dependent on the C57BL/ 6 background is the MP4-induced EAE (133). MP4 is a fusion protein that consists of the human isoform of myelin basic protein (MBP) and the three hydrophilic domains of proteolipid protein (PLP). Using this model several studies have successfully demonstrated both antibody-dependent and -independent roles of B cells in EAE (which mirrors aspects of the human disease as well). This includes induction of demyelination through complement activation $(76,134)$ and a pathogenic role for antibodies (133, 135). Of interest, B cell infiltrates are also present in the spinal cord, brain and cerebellum of MP4-immunized mice (136). In particular, aggregation of $B$ cells that acquired features of lymphoid tissue in the chronic disease stage was detected in the cerebellar parenchyma. A detailed characterization of these B cell aggregates in MP4-induced EAE revealed that the lymphoid structures in MP4-induced EAE were segregated into a B cell and $\mathrm{T}$ cell zone, which is similar to secondary lymphoid tissues where $\mathrm{B}$ cells reside in the follicles and $\mathrm{T}$ cells in the parafollicular zone. Furthermore, in MP4-induced EAE, high endothelial venules (HEVs) expressing the addressins CCL19 and CCL21 were also detected in addition to the chemoattractant CXCL13 $(83,137)$. Heavily proliferating $\mathrm{B}$ cells were also found indicating recent and clonal activation $(137,138)$. Collectively, these findings from the MP4-induced EAE model support a strong role for B cells in MS that is not only restricted to their antibody secreting ability. While the limited availability of human tissue in conjunction with the fact that autopsied brain tissue of MS patients only provides a "snapshot," this B cell-dependent EAE model can be exploited to answer a number of disease relevant questions. For example, time course experiments on the development of B cell follicles and studies to investigate whether B cells play a different role depending on the disease stage at which they are found can be demonstrated using this EAE model.

\section{Role of B Cells in MS: Lessons From Rodent Models of EAE}

Studies done in other EAE models have also revealed some important aspects of $\mathrm{B}$ cell involvement in disease progression and pathogenesis with some of the examples mentioned below.

As mentioned earlier, B cells can function as effective APCs especially when they recognize the same antigen as T cells (139). This antigen presenting capacity of B cells has been highlighted in different B cell-dependent EAE-based studies. In EAE induced by recombinant myelin oligodendrocyte glycoprotein (rMOG) protein, activated B cells have been shown to serve as APCs that promote the differentiation and proliferation of Th1 and Th17 cells. Accordingly, anti-CD20-mediated depletion of B cells inhibited B cell-dependent activation of pathogenic T cells contributing to the overall reduction of CNS inflammation (140). Furthermore, using an adoptive transfer model of EAE, it has been demonstrated that the development of autoimmune attacks within the CNS is facilitated by induction of MHC class II on $\mathrm{B}$ cells followed by pathogenic cognate interactions between Band T cells (141). Similarly, B cell-specific MHC class II knockout $(\mathrm{KO})$ mice have been found to be resistant to rMOG-induced disease indicating that $\mathrm{B}$ cells provide critical cellular functions independent of their humoral involvements (142).

A more favorable role of B cells in EAE has been elaborated in mice which did not express the anti-inflammatory cytokine IL-35. These mice also lost their ability to recover from $\mathrm{T}$ cell-mediated EAE confirming the importance of IL-10/IL-35 secreting B cells in ameliorating disease progression (143). Regulatory roles for B cells during EAE immunopathogenesis have also been discussed by other groups (144). A recent study highlights that non-selective depletion of B cells using antiCD20 therapy concurrently abolishes preexisting regulatory B cells which are important for limiting chronic disease progression (145). Efforts to expand our understanding of this regulatory population of $\mathrm{B}$ cells in improving EAE severity and reducing neuroinflammation is a current topic of interest.

Taken together, there is plenty of evidence from studies done in animal models and from MS itself which repeatedly points towards a definite role of $\mathrm{B}$ cells in aggravating disease pathogenesis in more than one way. In addition, there is also indication of an anti-inflammatory cytokine secreting "beneficial" population of B cells in both MS patients (repopulating IL-10 secreting B cells following CD20 depletion therapy) (32) and its EAE animal model (143). Nevertheless, 


\section{Multiple sclerosis/EAE}

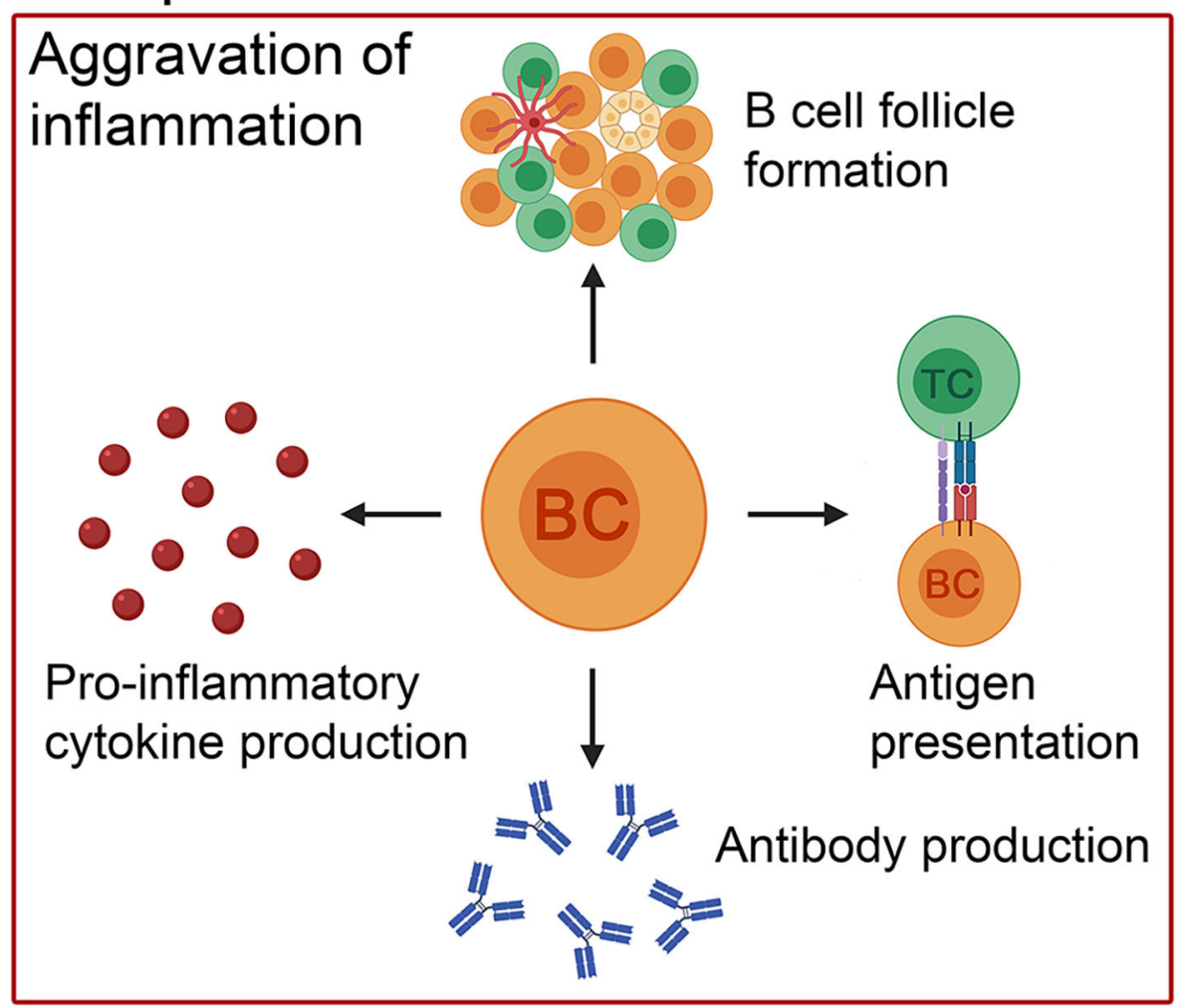

\section{Control of inflammation}

Anti-inflammatory
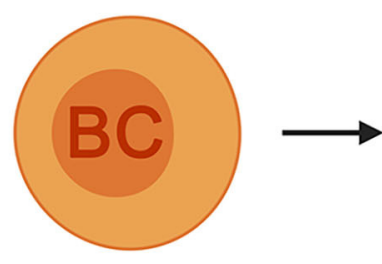
cytokine production

FIGURE 1 | The pathogenic and beneficial effects of B cells in MS patients and in its animal model, EAE. In addition to antibody production, B cells present antigens to T cells, form ectopic lymphoid structures consisting of B- and T-cell compartments, follicular dendritic cells and high endothelial venules and produce pro-inflammatory cytokines to exacerbate the disease course. Besides the negative role of this cell population, there is evidence that B cells positively influence the disease course by secreting anti-inflammatory cytokines. BC, B cell; TC, T cell.

several unanswered questions remain including, whether the pathogenic B cell subset(s) in MS patients can be selectively depleted, based on a more detailed characterization of this cell population. Longitudinal studies to monitor changes in the pro- vs. anti-inflammatory B cell subsets in the different compartments of MS patients (or in relevant EAE models) would also provide new insights into how B cells promote or reduce neuroinflammation, respectively. Finally, it would also be interesting to explore whether these new findings can be translated into therapeutic potentials and treatment options for patients (Figure 1).

\section{Infectious Neuroinflammation: A Focus on} Viral Diseases

As evident by the studies discussed above, the involvement of B cells as multifunctional players in MS as an example of autoimmune neuroinflammation is clear. However, as mentioned earlier, neuroinflammation can result from several other insults to the CNS which is not just restricted to being autoimmune (146). Infectious diseases of the CNS also result in neuroinflammation as an inherent host-defense mechanism to restore the normal function of the brain against the infecting pathogen (147). The importance of B cells, in general, in 
providing several lines of defense against a variety of pathogens and the ability of antibodies as their effector molecules in eliminating viral particles is very well established and has been discussed elsewhere (148-151). Therefore, neuroinflammation can be considered a common denominator between these two infectious and autoimmune triggers where B cells play a significant role. It is also intuitive that the "gaps" in our understanding of the contribution of B cells in autoimmune neuroinflammation, as discussed earlier, can be compensated by drawing parallels between the findings in infectious and autoimmune neuroinflammation with a focus on the involvement of B cells in both cases.

In that context, we discuss a few examples of viral infections of the CNS where B cells have been indicated to play a role in either clearing of the pathogen or progression of the infection. Furthermore, we have included examples of viral infections that are particularly relevant for MS. However, details of B cell activation in the different types of viral infections related to the CNS is beyond the scope of this review.

\section{Viral Infections of the CNS}

Viral infections of the CNS are the most prevalent cause of encephalitis, meningitis as well as meningoencephalitis and the number of cases surpasses all bacterial, fungal, protozoal infections combined $(152,153)$. Following viral infections of the CNS, inflammation can occur in different anatomical regions including the meninges, brain parenchyma, the spinal cord or simultaneously in multiple regions. Examples of viral infections affecting the CNS include herpes simplex virus, adenoviruses, arboviruses, flaviviruses, and enteroviruses (154). The complexity of these viral infections is influenced by a number of different factors including the tropism of the viruses, their routes of CNS entry as well as the overall "health" of the immune system (152).

John Cunningham virus (JCV) is an important example to learn about the interplay between opportunistic viral replication and the adaptive immune system. JCV infection of the CNS is associated with improper functioning of the adaptive immune system with relation to both the $\mathrm{B}$ - and $\mathrm{T}$ cell compartments (155). The occurrence of progressive multifocal leucoencephalopathy (PML), an oftentimes deadly demyelinating disease caused by JC virus replication in the brain, has been linked to immunomodulatory treatments in patients with autoimmune diseases (156), and is also observed in immunocompromised individuals or those with hematological malignancies. B cells appear to play a complex role in mediating disease pathogenesis of PML because on the one hand, they represent a potential reservoir for JCV and on the other hand they likely play a role in the control of the infection (157). Evidence from clinical studies and those done in animal models suggests that $\mathrm{B}$ cells not only influence the $\mathrm{T}$ cell response through cytokine secretion but are also able to mount an effective humoral response against the virus which together allows the control of infection (157). Although being a very rare event, the occurrence of PML has been linked to anti-CD20 depletion therapies, indicating a potential importance of B cells in controlling JCV infection (155, 158). In general, it has been suggested that profound perturbation of $\mathrm{B}$ cell homeostasis by anti-CD20 therapies (as in the case of rituximab) could contribute to the development of PML (155). For instance, following anti-CD20 depletion the reconstituted $\mathrm{B}$ cell pool is mostly considered to be IL- $10^{+}(112,115)$, with IL-10 being an anti-inflammatory cytokine that suppresses both $\mathrm{T}$ cell- and innate cell-mediated inflammatory responses. Whether this change in the overall $\mathrm{B}$ cell cytokine profile together with the phenotype of the newly appearing B cells aggravates the pathogenesis of PML is a current topic of investigation (155). Nevertheless it is important to stress that anti-CD20 therapy associated PML in MS patients is an extremely rare complication compared to treatment with, for instance, natalizumab (156).

\section{Animal Models of Virus-Induced Neuroinflammation}

Owing to the limited availability of patient material, the involvement of B cells in most viral infections of the CNS comes from the relevant animal models $(159,160)$. Through these various models it becomes well-established that B cells can play both detrimental as well as beneficial roles during CNS infection with encephalitic RNA viruses, such as Sindbis virus (SINV), Semliki forest virus (SFV), West Nile virus (WNV), neurotropic coronavirus, and murine cytomegalovirus (MCMV).

For instance, infection of mice with SFV suggests that brain infiltrating $B$ cells contribute to myelin injury in SFV encephalomyelitis in both an antibody-dependent and independent manner (161).

Extending the role of $\mathrm{B}$ cells beyond their capacity to modulate $\mathrm{T}$ cell functions, the study by Mutnal et al. is of note, where the authors demonstrate a distinctive subset of $\mathrm{CD}^{+} \mathrm{B}$ regulatory cells to infiltrate brains of mice chronically infected with MCMV. This population of regulatory B cells was found to control macrophage-dependent pro-inflammatory responses while absence of this cell population resulted in exacerbated $\mathrm{T}$ cell-mediated neuroinflammation post viral infection (162). In another mouse model using attenuated rabies virus it has been shown that the production of rabies-specific antibody by CNS tissue infiltrating B cells is essential for the complete elimination of the virus (163). Furthermore, studies done in mice infected with WNV have shown that B cells are critical in providing defense against early spread of infection in these mice as well as limiting infection in the CNS (164).

While the data mentioned above highlight some of the dual functions that B cells play in virus-induced neuroinflammation, numerous studies using viral models have focused on specific chemotactic signatures that allow B cell migration into the CNS.

Infection of the CNS with the neurotropic strain of mouse hepatitis virus (JHMV) in a murine model results in an acute CNS inflammatory response containing B cells (165). Antibody secreting cells were directed toward the CNS in a virus-induced chemotactic manner where CXCL9 and CXCL10 were identified as two such chemokines induced by JHMV (165). On the other hand, CXCR3 has also been identified as a chemokine receptor recruiting plasmablasts to the CNS in the same murine viral model (166). In response to another viral strain, SINV, a similar trend was noticed where CXCL13 and CCL19 were induced 
in the brains of mice infected with the virus (167). Similarly, during MCMV infection of the brain, $\mathrm{CD} 19^{+} \mathrm{B}$ cells isolated from the brain expressed chemokine receptors CXCR3, CXCR5, CCR5, and CCR7 (168). Overall, results from the different animal models of viral infections suggest CNS infiltrating $B$ cells during viral infection migrate into the CNS in a CXCR3-, CXCR5-, and CCR7-dependent manner whose ligands are also upregulated within the CNS (169).

While most of the above-mentioned studies highlight CXCL13 (the ligand for CXCR5) as an essential B cell chemotactic factor, interestingly, during coronavirus encephalomyelitis infection in mice, naïve and early activated $\operatorname{IgD}^{+} \mathrm{B}$ cells were able to migrate into the CNS independent of CXCL13-driven signals (170). This of course suggests a more complex chemokine kinetics over the course of an infection representing several possible "windows of trafficking" for B cells into the CNS. Accordingly, the subset and phenotype of B cells which migrate into the CNS may change depending on the time point.

Not only do viral models of inflammation give clues on migration patterns of $\mathrm{B}$ cells into the CNS but studies done in different viral models also present evidence that the CNS provides the necessary signals, including the expression of $\mathrm{B}$ cell activating factor (BAFF), for sustained B cell viability and maintenance of a repertoire of virus-specific antibody secreting cells within the CNS $(165,168,171)$. Additionally, an increased expression of BAFF mRNA in the CNS also coincides with longterm maintenance of virus-specific antibody secreting B cells in the brain (167). Sustained local antibody secretion by already infiltrated B cells in the brain seems to be an effective strategy in case of chronic viral infections of the CNS since the passage of antibodies from the periphery through intact brain barriers is insufficient (168). Another example of the CNS fostering B cell survival and differentiation comes from the Theiler's murine encephalomyelitis virus-induced demyelinating disease (TMEV-IDD) model. TMEV-IDD induced by injecting a virus into susceptible mice strains captures several aspects of chronic inflammation as seen in the progressive stages of MS (172). Using this model, during chronic infection, the predominant B cell phenotypes accumulating in the CNS were characterized to include isotype-switched B cells, memory B cells and antibody secreting cells. Mature and isotype-switched B cells were detected in the meninges and perivascular space and $\mathrm{B}$ cell relevant chemokines and tropic factors were elevated in the CNS in the absence of ectopic B cell follicles. Therefore, results from these studies revealed that the CNS has the ability to promote accumulation of isotype-switched B cells as well as intrathecal antibody synthesis independent of ectopic B cell follicle-like structures during chronic inflammation $(173,174)$ (Figure 2).

\section{Viral Infections Related to MS}

On one hand, the involvement of B cells in the context of viral infections resulting in neuroinflammation can be emphasized by the examples mentioned above. On the other hand, viruses as infectious agents in the etiology of MS have been suspected for several decades (175). Here, we discuss the interplay between viral infections and MS with a special focus on Epstein-Barr virus $(\mathrm{EBV})$.

\section{Epstein-Barr Virus (EBV)}

Among infectious factors, EBV has the strongest epidemiological and serological connection to MS (176-178) and a relationship between EBV infection with the MS brain has long been explored. While some studies suggest that EBV may be responsible for breaking immune tolerance to CNS myelin antigens through molecular mimicry (179), others focus on the ability of the virus to infect and promote immortalization of antibody secreting B cell clones (180). It has also been suggested that the virus can act as a possible antigenic stimulus of lasting immune response within the CNS with a link to the presence of persisting OCBs (181).

EBV is a ubiquitous B-lymphotropic virus with the ability to infect, activate and latently persist in B cells for the lifetime of the infected individual (182). Furthermore, EBV is known to drive an infected B cell out of its resting state to become activated into a B cell blast and eventually become a memory B cell that can circulate in the blood (182). Suggestions have been made that when EBV-infected B cells from the periphery migrate into the CNS, they play a crucial role in propagating CNS-compartmentalized neuroinflammation $(183,184)$. Given that the general opinion for development of MS pathology is thought to involve interactions between $\mathrm{T}$ - and $\mathrm{B}$ cells, whether EBV-infected B cells can also activate T cells in the periphery is an attractive hypothesis (183).

Elaborate histopathological evidence demonstrating a direct link between EBV and B cells comes from the work of Aloisi and others (185) where they repeatedly identified the presence of EBV-infected B cells "exclusively" in the brain of MS patients $(180,181,186)$ and not in corresponding control patients. In particular, areas with heavy B cell infiltrates have been identified as major sites of viral persistence (186).

Interestingly, a link between EBV infection and induction of human endogenous retoviral proteins on $\mathrm{B}$ cells has also been made (187). For example, the activation of the human endogenous retrovirus (HERV) has been suggested to be made in the presence of EBV infection where high quantities of HERV$\mathrm{W}$ proteins are said to be expressed on the surface of $\mathrm{B}$ cells in patients with active MS (188).

Nevertheless, it is important to note that other studies have failed to establish any relationship between EBV infection, B cells and MS $(189,190)$ leaving this question to what extent (if at all) EBV might be involved in MS open-ended (Figure 3).

\section{Cytomegalovirus (CMV)}

CMV is a latent virus that is known to cause chronic activation of the immune system (191) with the seroprevalence of CMV in the general population being between 45 and 100\% (192). An association between CMV infection and MS risk has been made in the past but with inconsistent results $(193,194)$.

Nevertheless, most studies have found that CMV seropositivity is negatively associated with MS $(195,196)$ with reports suggesting that $\mathrm{CMV}$ infection modulates the immune response to a regulatory type $(196,197)$. More recently it has been demonstrated that CMV infection regulates the distribution of B cell subsets in MS patients to a reduced proinflammatory phenotype (198) - a finding similar to what has 


\section{Viral infection}
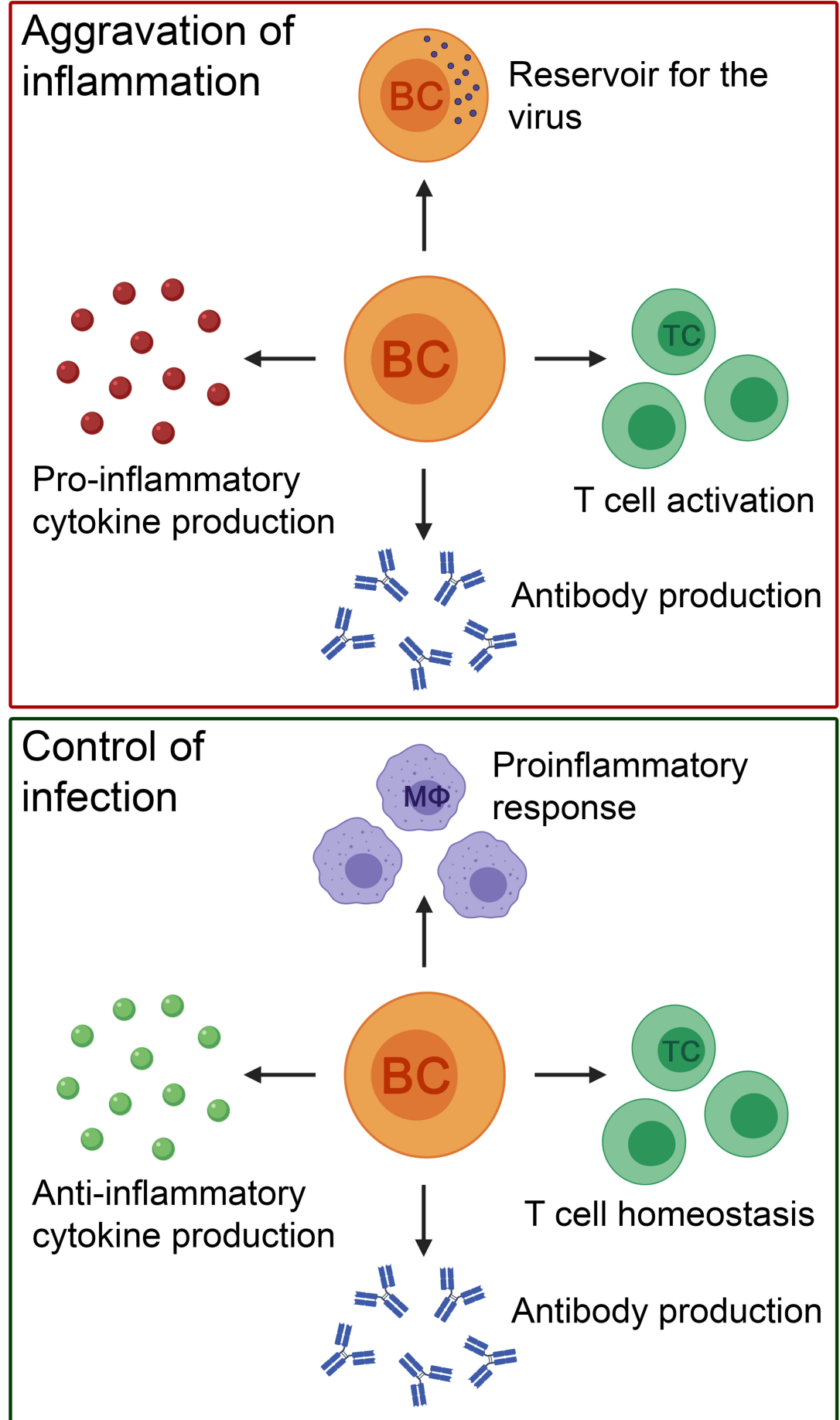

FIGURE 2 | The pathogenic and beneficial effects of B cells in patients with viral infections of the CNS and their corresponding animal models. B cells can cause aggravation of inflammation by pro-inflammatory cytokine and antibody production. In addition, they can act as a reservoir for the virus, and activate $T$ cells. Nevertheless, the role of B cells in viral infections is heterogenous. B cells control the infection by producing anti-inflammatory cytokines and antibodies to eliminate the virus. Furthermore, they have a positive effect on other immune cells by promoting $T$ cell homeostasis and controlling innate immune cell-mediated pro-inflammatory responses (e.g., by macrophages). BC, B cell; TC, T cell; M $\Phi$, macrophage. 


\section{The effect of EBV on B cells in multiple sclerosis}

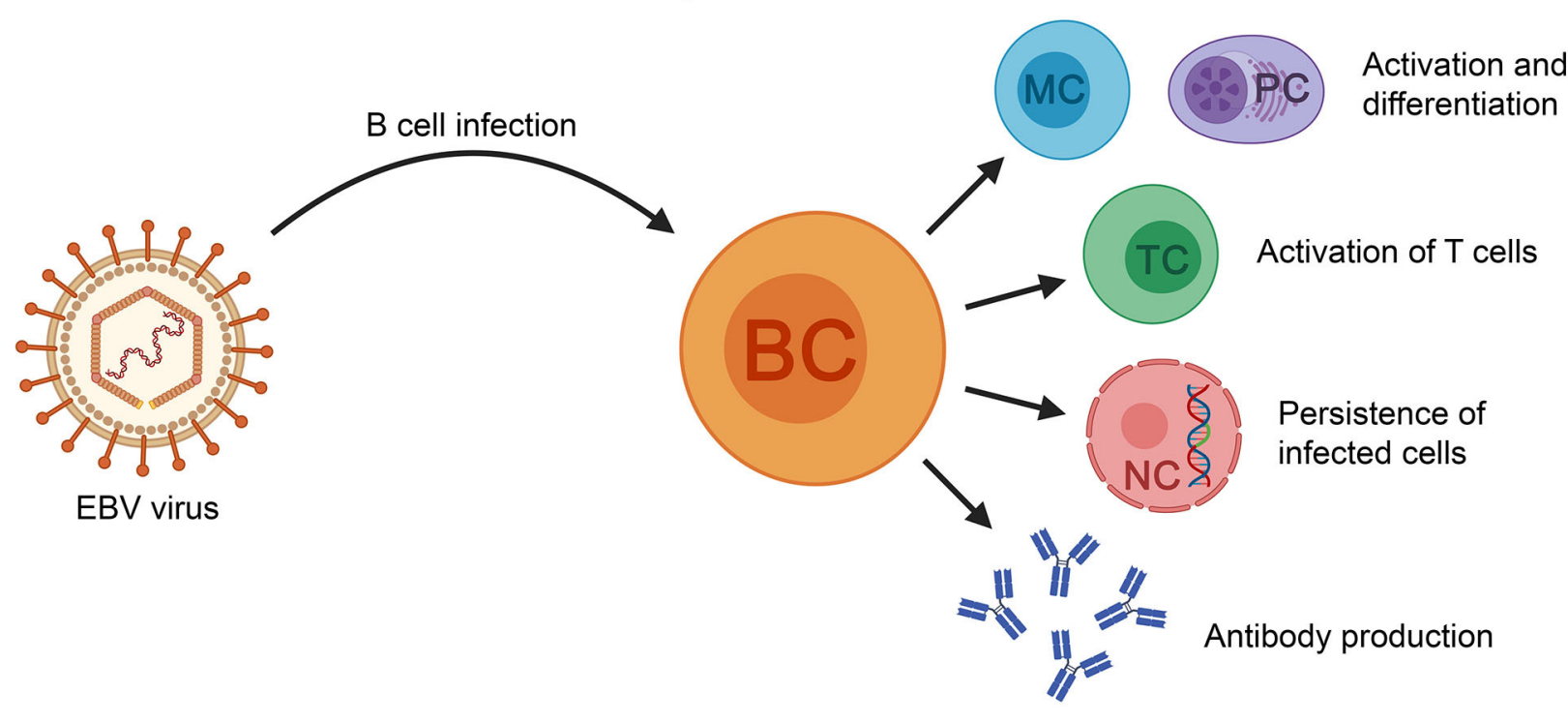

FIGURE 3 | The effect of EBV on B cells in the context of MS. EBV-infected B cells can activate T cells, as well as differentiate into memory B cells and antibody secreting plasma cells (PC). The virus can persist in the infected B cells for the lifetime of the patient. BC, B cell; MC, memory B cell; NC, nucleus; PC, plasma cell; $\mathrm{TC}, \mathrm{T}$ cell.

been previously described in the case of chronic CMV infection (199). Another hypothesis of how CMV may result in milder MS symptoms could be that in patients that are CMV/EBV double seropositive, there is a balance in the immune response between these two viruses (196). However, in CMV seronegative patients, EBV could drive the immune system towards a more aggressive MS disease phenotype.

Other mechanisms by which CMV might influence MS pathogenesis can be via molecular mimicry or bystander activation $(196,200)$.

In summary, the interaction between different viruses and the immune system-in particular B cells-in MS patients seems complex with contradictory findings. Further longitudinal studies with larger patient cohorts and rigorous methodologies are required to unravel the relationship between viral infections and disease initiation as well as progression in MS.

\section{MS vs. Virus-Induced Neuroinflammation}

It is reasonable to say that the basics of B cell biology remain the same independent of the trigger of neuroinflammation. Therefore, transferring the findings from one field of research to another may not only allow us to tackle the "unknown" better but also to look at the disorder from another perspective. As evident from the different studies mentioned above, several parallels can be drawn between virus-induced and autoimmune neuroinflammation. Here we discuss a few such examples.

Studies done in murine models of neurotropic viral infections indicate that B cells enter the CNS during acute viral infection with early infiltrating B cells expressing CXCR3 and CXCR5 (among others) and upregulation of the corresponding ligands in the CNS (169). A similar situation is observed in MS where
CXCL12 and CXCL13 are elevated in actively demyelinating MS lesions $(91,201)$, fostering B cell entry into the CNS. Additional evidence suggests the chemokines CXCL10, CCL2, and CCL3 also to be involved in attracting $\mathrm{B}$ cells into the CNS in MS (202). Therefore, B cells in general appear to have a specific and common chemotactic signature that allows them to migrate into the CNS under neuroinflammatory conditions whether the source is infectious or autoimmune.

Moreover, if one was to apply the findings in the viral model (as mentioned above) by the group of Phares et al. (170) to MS, it is indeed plausible that there is a variation in the chemotactic factors in the CSF/serum over the course of the disease. This plausible time-dependent change in chemokines in MS patients may also affect the phenotype of $\mathrm{B}$ cells migrating into the CNS. However, given the difficulties of following this "range" of migration pattern of B cells into the CSF/CNS compartment in MS patients, the question remains open.

While these are a few instances of the chemotactic "signature" behind the migration of $\mathrm{B}$ cells into the CNS, there are also similarities between viral models and MS with respect to how the B cells may be able to establish themselves within the inflamed brain. For example, in line with findings from viral models (167), strong astrocytic expression of BAFF in MS lesions (87) supports B cell survival making them active participants of "trapped inflammation" (in the case of SPMS) (203). Enough circumstantial evidence suggests that through the expression of the necessary B cell survival factors, the MS brain creates an environment that is conducive for the retention of $\mathrm{B}$ cells within the CNS $(87,91,202)$.

To what extent B cells can "establish" themselves within the CNS and the role(s) they play from within this compartment 
have been discussed using both viral models and EAE. Using the TMEV-IDD model DiSano et al. suggest that aggregates of B cells, independent of ectopic lymphoid-like follicle structures, are sufficient to drive $\mathrm{B}$ cell differentiation and also contribute to intrathecal antibody synthesis (173). This is an important finding because while there may not be an obvious presence of ectopic B cell follicles in all cases of progressive MS $(189,204)$, prominent $\mathrm{CD}^{+} 0^{+} \mathrm{B}$ cells infiltrates or clusters are detected in a higher percentage of MS patients $(79,189)$. Although the significance of these B cell clusters has not been well-discussed in the field of MS research, it might be interesting to see if these $B$ cells also

\section{Multiple sclerosis vs. virus-induced neuroinflammation (mouse \& human)}

\section{Specific chemotactic signature for $B$ cell migration into the CNS}

Multiple sclerosis:

CXCL10, CXCL12, CXCL13, CCL2, CCL3 and CCL21
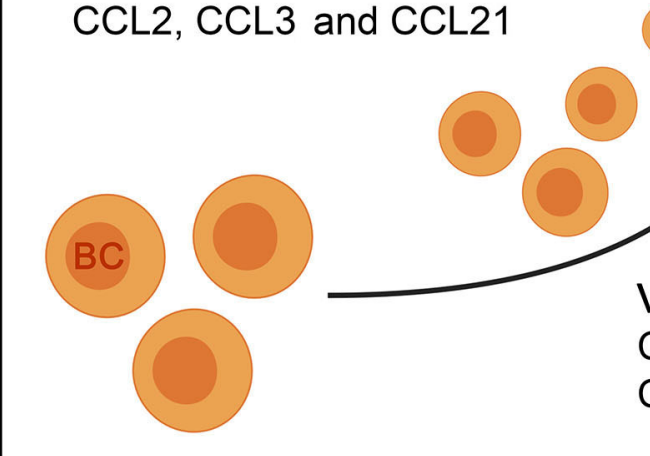

Survival factor for B cells in the CNS

\section{Multiple sclerosis and} viral infection:

BAFF, APRIL

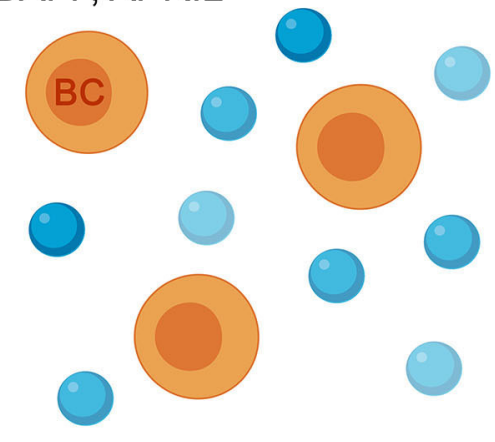

\section{Ongoing immune processes in the CNS}

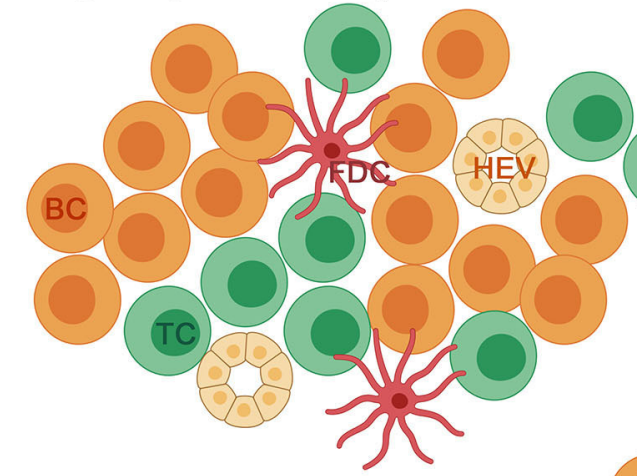

Viral infection:

$B$ cell aggregates without lymphoid follicle character
Multiple sclerosis: ectopic lympoid $B$ cell follicles

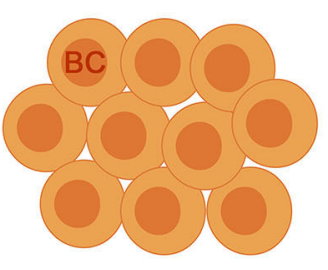

Regulation of inflammation

Multiple sclerosis and viral infection: $\mathrm{CD}^{+} \mathrm{B}$ cells

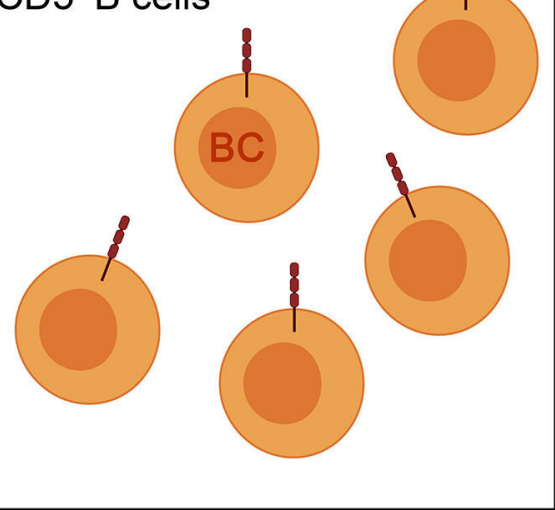

FIGURE 4 | The comparison of autoimmune and infectious neuroinflammation in mouse and humans. Both diseases show a specific chemotactic signature for B cell migration into the CNS. The retention of B cells in the CNS is supported by survival factors, like BAFF and APRIL, in autoimmune and infectious neuroinflammation. B cells form aggregates during the disease course. The aggregates occurring in autoimmune diseases, like MS, can develop lymphoid follicle-like features, with compartmentalization of B cells and T cells, follicular dendritic cells and high endothelial venules, unlike in viral infection. For regulation of inflammation, CD5 ${ }^{+}$B cells are found in both kinds of neuroinflammation. BC, B cell; FDC, follicular dendritic cell; HEV, high endothelial venule; TC, T cell. 
participate in similar functions as observed in the TMEVIDD model.

The significance of a specific regulatory subset of $\mathrm{CD}^{+}$ $\mathrm{B}$ cells in the CNS following chronic viral infection has been demonstrated in animal models (162). The role of $\mathrm{CD}^{+} \mathrm{B}$ cells with a potent regulatory capacity $(205,206)$ has been reviewed previously (207, 208). Interestingly, clinical data from MS patients suggest that regulatory $B$ cells with increased expression of CD5 predominantly repopulate following anti-CD20 treatment, whichwhen activated-secrete more anti-inflammatory IL-10 (209). Among other functions, the immunosuppressive cytokine IL-10 is also associated with $\mathrm{T}$ cell exhaustion allowing control of aggressive disease progression and preventing excessive tissue injury (210). Indeed, in MS, where demyelination and aggressive disease progression are associated with the presence of $\mathrm{T}$ cells (211), exploiting this immunoregulatory subset of IL-10 secreting $\mathrm{CD}^{+} \mathrm{B}$ cells to dampen neuroinflammation remains a current research focus (Figure 4).

\section{CONCLUDING REMARKS}

The contribution of B cells to CNS neuroinflammatory diseases is unambiguous, as demonstrated by the examples mentioned above. One can say that the $\mathrm{B}$ cell response in neuroinflammation is complex and comprises a combination of both beneficial and detrimental phenotypes. Furthermore, the nature of the B cell response differs considerably between the different stages of the disease.

\section{REFERENCES}

1. Dörner T, Jacobi AM, Lipsky PE. B cells in autoimmunity. Arthritis Res Ther. (2009) 11:247. doi: 10.1186/ar2780

2. Hampe CS. B cells in autoimmune diseases. Scientifica. (2012) 2012:215308. doi: 10.6064/2012/215308

3. Lund FE, Randall TD. Effector and regulatory B cells: modulators of CD4+ T cell immunity. Nat Rev Immunol. (2010) 10:236-47. doi: 10.1038/ nri2729

4. León B, Ballesteros-Tato A, Misra RS, Wojciechowski W, Lund FE. Unraveling effector functions of B cells during infection: the hidden world beyond antibody production. Infect Disord Drug Targets. (2012) 12:213-21. doi: 10.2174/187152612800564437

5. Lund FE. Cytokine-producing B lymphocytes-key regulators of immunity. Curr Opin Immunol. (2008) 20:332-38. doi: 10.1016/j.coi.2008.03.003

6. Lanzavecchia A, Bove S. Specific B lymphocytes efficiently pick up, process and present antigen to T cells. Behring Inst Mitt. (1985) 77:82-87.

7. Hofmann K, Clauder A-K, Manz, RA. Targeting B cells and plasma cells in autoimmune diseases. Front Immunol. (2018) 9:835. doi: 10.3389/fimmu.2018.00835

8. Shen P, Fillatreau S. Antibody-independent functions of B cells: a focus on cytokines. Nat Rev Immunol. (2015) 15:441-51. doi: 10.1038/nri3857

9. Petersone L, Edner NM, Ovcinnikovs V, Heuts F, Ross, EM, Ntavli E, et al. T cell/B cell collaboration and autoimmunity: an intimate relationship. Front Immunol. (2018) 9:1941. doi: 10.3389/fimmu.2018. 01941

10. Rydzewska M, Jaromin M, Pasierowska IE, Stozek K, Bossowski A. Role of the $\mathrm{T}$ and $\mathrm{B}$ lymphocytes in pathogenesis of autoimmune thyroid diseases. Thyroid Res. (2018) 11:2. doi: 10.1186/s13044-018-0046-9
Following limitations of human studies, it is often necessary to extend our understanding of the involvement and importance of a particular cell type by performing experiments in appropriate animal models. Most of the animal disease models used to identify mechanisms that underlie neuroinflammation are induced artificially while mimicking all aspects of a human disease in a single animal model is not feasible. Researchers working on a particular disease often tend to use models which are within their specific area of research, while neglecting the relevance of the findings from other disease models. As an example in this review we have compared studies done in animal models of virus-induced neuroinflammation to findings in MS, although similar comparisons between other instances of neuroinflammation can also be established. It can be assumed that application of the findings from infectious neuroinflammation (with respect to the involvement of B cells) to the field of autoimmune neuroinflammation may facilitate the development of novel therapies to tackle neuroinflammatory disorders like MS and vice versa.

\section{AUTHOR CONTRIBUTIONS}

RC and VS outlined the subject of the review, searched for and interpreted the literature, prepared the figures, wrote the manuscript, and gave final approval of the version for publication. SK edited and revised the manuscript for important intellectual content and gave final approval of the version for publication. All figures were created with BioRender.com. All authors contributed to the article and approved the submitted version.

11. Choi SC, Morel L. B cell contribution of the CD4+ T cell inflammatory phenotypes in systemic lupus erythematosus. Autoimmunity. (2017) 50:3741. doi: 10.1080/08916934.2017.1280028

12. Fillatreau S. B cells and their cytokine activities implications in human diseases. Clin Immunol. (2018) 186:26-31. doi: 10.1016/j.clim.2017.07.020

13. Mauri C, Menon M. Human regulatory B cells in health and disease: therapeutic potential. J Clin Invest. (2017) 127:772-79. doi: 10.1172/JCI85113

14. Musette P, Bouaziz, JD. B cell modulation strategies in autoimmune diseases: new concepts. Front Immunol. (2018) 9:622. doi: 10.3389/fimmu.2018.00622

15. Mauri C, Bosma A. Immune regulatory function of B cells. Annu Rev Immunol. (2012) 30:221-41. doi: 10.1146/annurev-immunol-020711-074934

16. Sokolov AV, Shmidt AA, Lomakin YA. B cell regulation in autoimmune diseases. Acta Naturae. (2018) 10:11-22.

17. Yang M, Rui K, Wang S, Lu L. Regulatory B cells in autoimmune diseases. Cell Mol Immunol. (2013) 10:122-32. doi: 10.1038/cmi.2012.60

18. Lemoine S, Morva A, Youinou P, Jamin C. Regulatory B cells in autoimmune diseases: how do they work? Ann N Y Acad Sci. (2009) 1173:26067. doi: 10.1111/j.1749-6632.2009.04651.x

19. DiSabato DJ, Quan N, Godbout JP. Neuroinflammation: the devil is in the details. J Neurochem. (2016) 139:136-53. doi: 10.1111/jnc.13607

20. Carson MJ, Thrash JC, Walter B. The cellular response in neuroinflammation: the role of leukocytes, microglia and astrocytes in neuronal death and survival. Clin Neurosci Res. (2006) 6:237-45. doi: 10.1016/j.cnr.2006.09.004

21. Gendelman HE. Neural immunity: friend or foe? J Neurovirol. (2002) 8:47479. doi: 10.1080/13550280290168631

22. Schwartz M, Deczkowska A. Neurological disease as a failure of brainimmune crosstalk: the multiple faces of neuroinflammation. Trends Immunol. (2016) 37:668-79. doi: 10.1016/j.it.2016.08.001 
23. Ransohoff RM, Schafer D, Vincent A, Blachère NE, Bar-Or A. Neuroinflammation: ways in which the immune system affects the brain. Neurotherapeutics. (2015) 12:896-909. doi: 10.1007/s13311-015-0385-3

24. Ransohoff RM, Engelhardt B. The anatomical and cellular basis of immune surveillance in the central nervous system. Nat Rev Immunol. (2012) 12:62335. doi: 10.1038/nri3265

25. Engelhardt B, Vajkoczy P, Weller RO. The movers and shapers in immune privilege of the CNS. Nat Immunol. (2017) 18:123-31. doi: 10.1038/ni.3666

26. Marchetti L, Engelhardt B. Immune cell trafficking across the blood-brain barrier in the absence and presence of neuroinflammation. Vascular Biology. (2020) 2:H1-18. doi: 10.1530/VB-19-0033

27. Prinz M, Priller J. The role of peripheral immune cells in the CNS in steady state and disease. Nat Neurosci. (2017) 20:136-44. doi: 10.1038/nn.4475

28. Gredler V, Reindl M. B cells accumulate in the cerebrospinal fluid in inflammatory neurological diseases. J Cytol Histol. (2012) 1:e2559. doi: 10.1371/journal.pone.0002559

29. Kowarik MC, Grummel V, Wemlinger S, Buck D, Weber MS, Berthele A, et al. Immune cell subtyping in the cerebrospinal fluid of patients with neurological diseases. J Neurol. (2014) 261:130-43. doi: 10.1007/s00415-013-7145-2

30. Sabatino JJ, Pröbstel A-K, Zamvil SS. B cells in autoimmune and neurodegenerative central nervous system diseases. Nat Rev Neurosci. (2019) 20:728-45. doi: 10.1038/s41583-019-0233-2

31. Blauth K, Owens GP, Bennett JL. The ins and outs of B cells in multiple sclerosis. Front Immunol. (2015) 6:565. doi: 10.3389/fimmu.2015.00565

32. Li R, Patterson KR, Bar-Or A. Reassessing B cell contributions in multiple sclerosis. Nat Immunol. (2018) 19:696-707. doi: 10.1038/s41590-018-0135-x

33. Lehmann-Horn K, Kinzel S, Weber M. Deciphering the Role of B cells in multiple sclerosis-towards specific targeting of pathogenic function. Int J Mol Sci. (2017) 18:2048. doi: 10.3390/ijms18102048

34. Pieper K, Grimbacher B, Eibel H. B-cell biology and development. J Allergy Clin Immunol. (2013) 131:959-71. doi: 10.1016/j.jaci.2013.01.046

35. Melchers, F. Checkpoints that control B cell development. J Clin Invest. (2015) 125:2203-10. doi: 10.1172/JCI78083

36. Delves PJ, Martin SJ, Burton DR, Roitt IM. Roitt's Essential Immunology. 12th edn. Wiley-Blackwell (2011).

37. Punt J, Stranford S, Jones P, Owen JA. Kuby Immunology. 6th edn. W.H Freeman and Company (2012).

38. Wols, HAM. Plasma cells. eLS. (2006). Available online at: https:// onlinelibrary.wiley.com/doi/full/10.1038/npg.els.0004030

39. Cambier JC, Gauld SB, Merrell KT, Vilen BJ. B-cell anergy: from transgenic models to naturally occurring anergic B cells? Nat Rev Immunol. (2007) 7:633-43. doi: $10.1038 /$ nri2133

40. Rose NR. Molecular mimicry and clonal deletion: a fresh look. J Theor Biol. (2015) 375:71-76. doi: 10.1016/j.jtbi.2014.08.034

41. Sandel PC, Monroe JG. Negative selection of immature B Cells by receptor editing or deletion is determined by site of antigen encounter. Immunity. (1999) 10:289-99. doi: 10.1016/s1074-7613(00)80029-1

42. Hozumi N, Tonegawa S. Evidence for somatic rearrangement of immunoglobulin genes coding for variable and constant regions. Proc Natl Acad Sci USA. (1976) 73:3628-32. doi: 10.1073/pnas.73.10.3628

43. Zhang X. Regulatory functions of innate-like B cells. Cell Mol Immunol. (2013) 10:113-21. doi: 10.1038/cmi.2012.63

44. Shaffer AL, Rosenwald A, Staudt LM. Lymphoid malignancies: the dark side of B-cell differentiation. Nat Rev Immunol. (2002) 2:92032. doi: $10.1038 /$ nri953

45. Allman D, Pillai S. Peripheral B cell subsets. Curr Opin Immunol. (2008) 20:149-57. doi: 10.1016/j.coi.2008.03.014

46. Hua Z, Hou B. TLR signaling in B-cell development and activation. Cell Mol Immunol. (2013) 10:103-6. doi: 10.1038/cmi.2012.61

47. Avalos AM, Ploegh HL. Early BCR events and antigen capture, processing, and loading on MHC class II on B cells. Front Immunol. (2014) 5:92. doi: 10.3389/fimmu.2014.00092

48. Heinen E, Cormann N, Kinet-Denoël C. The lymph follicle: a hard nut to crack. Immunol Today. (1988) 9:240-43. doi: 10.1016/0167-5699(88)91223-6

49. Obukhanych TV, Nussenzweig MC. T-independent type II immune responses generate memory B cells. J Exp Med. (2006) 203:30510. doi: $10.1084 /$ jem. 20052036
50. McFarland HF, Martin R. Multiple sclerosis: a complicated picture of autoimmunity. Nat Immunol. (2007) 8:913-19. doi: 10.1038/ni1507

51. Disanto G, Berlanga AJ, Handel AE, Para AE, Burrell AM, Fries A, et al. Heterogeneity in multiple sclerosis: scratching the surface of a complex disease. Autoimmune Dis. (2010) 2011:932351. doi: 10.4061/2011/932351

52. Sospedra M, Martin R. Immunology of multiple sclerosis. Annu Rev Immunol. (2005) 23:683747. doi: 10.1146/annurev.immunol.23.021704.115707

53. Kutzelnigg A, Lucchinetti CF, Stadelmann C, Brück W, Rauschka H, Bergmann $\mathrm{M}$, et al. Cortical demyelination and diffuse white matter injury in multiple sclerosis. Brain. (2005) 128:2705-12. doi: 10.1093/brain/a wh641

54. Kuhlmann T. Relapsing-remitting and primary progressive MS have the same cause(s) - the neuropathologist's view: 2. Mult Scler. (2013) 19:26869. doi: $10.1177 \% 2 \mathrm{~F} 1352458513476563$

55. Lassmann H. What drives disease in multiple sclerosis: inflammation or neurodegeneration? Clin Exp Neuroimmunol. (2010) 1:2-11. doi: 10.1111/j.1759-1961.2009.00003.x

56. Cross AH, Waubant E. MS and the B cell controversy. Biochim Biophys Acta. (2011) 1812:231-38. doi: 10.1016/j.bbadis.2010.07.020

57. Prat A, Antel J. Pathogenesis of multiple sclerosis. Curr Opin Neurol. (2005) 18:225-30. doi: 10.1097/01.wco.0000169737.99040.31

58. Dendrou CA, Fugger L, Friese MA. Immunopathology of multiple sclerosis. Nat Rev Immunol. (2015) 15:545-58. doi: 10.1038/nri3871

59. Claes N, Fraussen J, Stinissen P, Hupperts R, Somers, V. B cells are multifunctional players in multiple sclerosis pathogenesis: insights from therapeutic interventions. Front Immunol. (2015) 6:642. doi: 10.3389/fimmu.2015.00642

60. Kerfoot SM, Yaari G, Patel JR, Johnson KL, Gonzalez DJ, Kleinstein $\mathrm{SH}$, et al. Germinal center $\mathrm{B}$ cell and $\mathrm{T}$ follicular helper cell development initiates in the interfollicular zone. Immunity. (2011) 34:947-60. doi: 10.1016/j.immuni.2011.03.024

61. Franciotta D, Salvetti M, Lolli F, Serafini B, Aloisi F. B cells and multiple sclerosis. Lancet Neurol. (2008) 7:85258. doi: 10.1016/S1474-4422(08)70192-3

62. Sospedra M. B cells in multiple sclerosis. Curr Opin Neurol. (2018) 31:25662. doi: 10.1097/WCO.000000000000563

63. Häusser-Kinzel S, Weber MS. The role of B Cells and antibodies in multiple sclerosis, neuromyelitis optica, and related disorders. Front Immunol. (2019) 10:201. doi: 10.3389/fimmu.2019.00201

64. Arneth BM. Impact of B cells to the pathophysiology of multiple sclerosis. $J$ Neuroinflammation. (2019) 16:128. doi: 10.1186/s12974-019-1517-1

65. Link H, Huang, YM. Oligoclonal bands in multiple sclerosis cerebrospinal fluid: an update on methodology and clinical usefulness. J Neuroimmunol. (2006) 180:17-28. doi: 10.1016/j.jneuroim.2006.07.006

66. Deisenhammer F, Zetterberg H, Fitzner B, Zettle UK. The cerebrospinal fluid in multiple sclerosis. Front Immunol. (2019) 10:726. doi: 10.3389/fimmu.2019.00726

67. Naegele M, Martin R. The good and the bad of neuroinflammation in multiple sclerosis. Handb Clin Neurol. (2014) 122:5987. doi: 10.1016/B978-0-444-52001-2.00003-0

68. Obermeier B, Mentele R, Malotka J, Kellermann J, Kümpfel T, Wekerle $\mathrm{H}$, et al. Matching of oligoclonal immunoglobulin transcriptomes and proteomes of cerebrospinal fluid in multiple sclerosis. Nat Med. (2008) 14:688-93. doi: 10.1038/nm1714

69. Cepok S, Rosche B, Grummel V, Vogel F, Zhou D, Sayn J, et al. Short-lived plasma blasts are the main B cell effector subset during the course of multiple sclerosis. Brain. (2005) 128:1667-76. doi: 10.1093/brain/awh486

70. Cepok S, von Geldern G, Grummel V, Hochgesand S, Selik H, Hartung $\mathrm{H}$, et al. Accumulation of class switched IgD-IgM- memory B cells in the cerebrospinal fluid during neuroinflammation. J Neuroimmunol. (2006) 180:33-9. doi: 10.1016/j.jneuroim.2006.06.031

71. Colombo M, Dono M, Gazzola P, Roncella S, Valetto A, Chiorazzi $\mathrm{N}$, et al. Accumulation of clonally related B lymphocytes in the cerebrospinal fluid of multiple sclerosis patients. J Immunol. (2000) 164:2782-89. doi: 10.4049/jimmunol.164.5.2782

72. Harp C, Lee J, Lambracht-Washington D, Cameron E, Olsen G, Frohman E, et al. Cerebrospinal fluid B cells from multiple sclerosis patients are subject 
to normal germinal center selection. J Neuroimmunol. (2007) 183:18999. doi: 10.1016/j.jneuroim.2006.10.020

73. Stern JN, Yaari G, Vander Heiden JA, Church G, Donahue WF, Hintzen RQ, et al. B cells populating the multiple sclerosis brain mature in the draining cervical lymph nodes. Sci Transl Med. (2014) 6:248. doi: 10.1126/scitranslmed.3008879

74. Palanichamy A, Apeltsin L, Kuo TC, Sirota M, Wang S, Pitts SJ, et al. Immunoglobulin class-switched B cells form an active immune axis between CNS and periphery in multiple sclerosis. Sci Transl Med. (2014) 6:248. doi: 10.1126/scitranslmed.3008930

75. Eggers EL, Michel BA, Wu H, Wang S-Z, Bevan CJ, Abounasr A, et al. Clonal relationships of CSF B cells in treatment-naive multiple sclerosis patients. JCI Insight. (2017) 2:e92724. doi: 10.1172/jci.insight.92724

76. Lucchinetti C, Brück W, Parisi J, Scheithauer B, Rodriguez M, Lassmann H. Heterogeneity of multiple sclerosis lesions: implications for the pathogenesis of demyelination. Ann Neurol. (2000) 47:707-17. doi: 10.1002/1531-8249(200006)47:6<707::aid-ana3>3.0.co;2-q

77. Lassmann H, Brück W, Lucchinetti C. Heterogeneity of multiple sclerosis pathogenesis: implications for diagnosis and therapy. Trends Mol Med. (2001) 7:115-21. doi: 10.1016/s1471-4914(00)01909-2

78. Frischer JM, Bramow S, Dal-Bianco A, Lucchinetti CF, Rauschka $\mathrm{H}$, Schmidbauer $\mathrm{M}$, et al. The relation between inflammation and neurodegeneration in multiple sclerosis brains. Brain. (2009) 132:117589. doi: 10.1093/brain/awp070

79. Machado-Santos J, Saji E, Tröscher AR, Paunovic M, Liblau R, Gabriely G, et al. The compartmentalized inflammatory response in the multiple sclerosis brain is composed of tissue-resident CD8+ T lymphocytes and B cells. Brain. (2018) 141:2066-82. doi: 10.1093/brain/awy151

80. Howell OW, Reeves CA, Nicholas R, Carassiti D, Radotra B, Gentleman SM, et al. Meningeal inflammation is widespread and linked to cortical pathology in multiple sclerosis. Brain. (2011) 134:2755-71. doi: 10.1093/brain/awr182

81. Magliozzi R, Howell OW, Vora A, Serafini B, Nicholas R, Puopolo M, et al. Meningeal B-cell follicles in secondary progressive multiple sclerosis associate with early onset of disease and severe cortical pathology. Brain. (2007) 130:1089-104. doi: 10.1093/brain/awm038

82. Magliozzi R, Howell OW, Reeves C, Roncaroli F, Nicholas R, Serafini B, et al. A gradient of neuronal loss and meningeal inflammation in multiple sclerosis. Ann Neurol. (2010) 68:477-93. doi: 10.1002/ana.22230

83. Serafini B, Rosicarelli B, Magliozzi R, Stigliano E, Aloisi F. Detection of ectopic B-cell follicles with germinal centers in the meninges of patients with secondary progressive multiple sclerosis. Brain Pathol. (2004) 14:16474. doi: $10.1111 / j .1750-3639.2004 . t b 00049 . x$

84. Choi SR, Howell OW, Carassiti D, Magliozzi R, Gveric D, Muraro PA, et al. Meningeal inflammation plays a role in the pathology of primary progressive multiple sclerosis. Brain. (2012) 135:2925-37. doi: 10.1093/brain/aws189

85. Mitsdoerffer M, Peters A. Tertiary lymphoid organs in central nervous system autoimmunity. Front Immunol. (2016) 7:451. doi: 10.3389/fimmu.2016.00451

86. Lovato L, Willis SN, Rodig SJ, Caron T, Almendinger SE, Howell OW, et al. Related B cell clones populate the meninges and parenchyma of patients with multiple sclerosis. Brain. (2011) 134:534-41. doi: 10.1093/brain/awq350

87. Reali C, Magliozzi R, Roncaroli, F, Nicholas R, Howell OW, Reynolds R. B cell rich meningeal inflammation associates with increased spinal cord pathology in multiple sclerosis. Brain Pathol. (2020) 30:779-93. doi: 10. org/10.1111/bpa.12841

88. Bernasconi NL, Traggiai E, Lanzavecchia A. Maintenance of serological memory by polyclonal activation of human memory B cells. Science. (2002) 298:2199-202. doi: 10.1126/science.1076071

89. Sanders VJ, Felisan S, Waddell A, Tourtellotte WW. Detection of herpesviridae in postmortem multiple sclerosis brain tissue and controls by polymerase chain reaction. J Neurovirol. (1996) 2:249-58. doi: 10.3109/13550289609146888

90. Derfuss T, Hohlfeld R, Meinl E. Intrathecal antibody (IgG) production against human herpesvirus type 6 occurs in about $20 \%$ of multiple sclerosis patients and might be linked to a polyspecific B-cell response. J Neurol. (2005) 252:968-71. doi: 10.1007/s00415-005-0794-z

91. Krumbholz M, Theil D, Derfuss T, Rosenwald A, Schrader F, Monoranu C-M, et al. BAFF is produced by astrocytes and up-regulated in multiple sclerosis lesions and primary central nervous system lymphoma. J Exp Med. (2005) 201:195-200. doi: 10.1084/jem.20041674

92. Krumbholz M, Theil D, Cepok S, Hemmer B, Kivisäkk P, Ransohoff RM, et al. Chemokines in multiple sclerosis: CXCL12 and CXCL13 up-regulation is differentially linked to CNS immune cell recruitment. Brain. (2006) 129:20011. doi: 10.1093/brain/awh680

93. Kowarik MC, Cepok S, Sellner J, Grummel V, Weber MS, Korn T, et al. CXCL13 is the major determinant for B cell recruitment to the CSF during neuroinflammation. J Neuroinflammation. (2012) 9:1-11. Available online at: https://jneuroinflammation.biomedcentral.com/articles/10.1186/ 1742-2094-9-93

94. Hauser SL, Waubant E, Arnold DL, Vollmer T, Antel J, Fox RJ, et al. B-cell depletion with rituximab in relapsing-remitting multiple sclerosis. $N$ Engl $J$ Med. (2008) 13:706383. doi: 10.1056/NEJMoa0706383

95. Salzer J, Svenningsson R, Alping P, Novakova L, Björck A, Fink $\mathrm{K}$, et al. Rituximab in multiple sclerosis: a retrospective observational study on safety and efficacy. Neurology. (2016) 87:2074-81. doi: 10.1212/WNL.0000000000003331

96. Cross AH, Stark JL, Lauber J, Ramsbottom MJ, Lyons J-A. Rituximab reduces $\mathrm{B}$ cells and T cells in cerebrospinal fluid of multiple sclerosis patients. $J$ Neuroimmunol. (2006) 180:63-70. doi: 10.1016/j.jneuroim.2006.06.029

97. Martin Mdel P, Cravens PD, Winger R, Kieseier BC, Cepok S, Eager TN, et al. Depletion of B lymphocytes from cerebral perivascular spaces by rituximab. Arch Neurol. (2009) 66:1016-20. doi: 10.1001/archneurol.2009.157

98. Topping J, Dobson R, Lapin S, Maslyanskiy A, Kropshofer H, Leppert D, et al. The effects of intrathecal rituximab on biomarkers in multiple sclerosis. Mult Scler Relat Disord. (2016) 6:49-53. doi: 10.1016/j.msard.2016.01.001

99. Komori M, Lin YC, Cortese I, Blake A, Ohayon J, Cherup J, et al. Insufficient disease inhibition by intrathecal rituximab in progressive multiple sclerosis. Ann Clin Transl Neurol. (2016) 3:166-79. doi: 10.1002/acn3.293

100. Martin R, Sospedra M, Rosito M, Engelhardt B. Current multiple sclerosis treatments have improved our understanding of MS autoimmune pathogenesis. Eur J Immunol. (2016) 46:2078-90. doi: 10.1002/eji.201646485

101. Montalban X, Hauser SL, Kappos L, Arnold DL, Bar-Or A, Comi G, et al. Ocrelizumab versus placebo in primary progressive multiple sclerosis. $N$ Engl J Med. (2017) 376:209-20. doi: 10.1056/NEJMoa1606468

102. Rodríguez-Pinto D. B cells as antigen presenting cells. Cell Immunol. (2005) 238:67-75. doi: 10.1016/j.cellimm.2006.02.005

103. Barnett LG, Simkins HM, Barnett BE, Korn LL, Johnson AL, Wherry EJ. B cell antigen presentation in the initiation of follicular helper $\mathrm{T}$ cell and germinal center differentiation. J Immunol. (2014) 192:360717. doi: 10.4049/jimmunol.1301284

104. Genç K, Dona DL, Reder AT. Increased CD80(+) B cells in active multiple sclerosis and reversal by interferon beta-1b therapy. J Clin Invest. (1997) 99:2664-71. doi: 10.1172/JCI119455

105. Marckmann S, Wiesemann E, Hilse R, Trebst C, Stangel M, Windhagen A. Interferon-beta up-regulates the expression of co-stimulatory molecules CD80, CD86 and CD40 on monocytes: significance for treatment of multiple sclerosis. Clin Exp Immunol. (2004) 138:499-506. doi: 10.1111/j.1365-2249.2004.02624.x

106. Mathias A, Perriard G, Canales M, Soneson C, Delorenzi M, Schluep M, et al. Increased ex vivo antigen presentation profile of B cells in multiple sclerosis. Mult Scler. (2017) 23:802-09. doi: 10.1177/1352458516664210

107. Miranda-Hernandez S, Baxter AG. Role of toll-like receptors in multiple sclerosis. Am J Clin Exp Immunol. (2013) 2:7593. doi: 10.1515/revneuro-2014-0026

108. Zheng C, Chen J, Chu F, Zhu J, Jin T. Inflammatory role of TLRMyD88 signaling in multiple sclerosis. Front Mol Neurosci. (2020) 12:314. doi: $10.3389 /$ fnmol.2019.00314

109. Sahoo NC, Rao KV, Natarajan K. CD80 expression is induced on activated B cells following stimulation by CD86. Scand J Immunol. (2002) 55:57784. doi: 10.1046/j.1365-3083.2002.01093.x

110. Jelcic I, Al Nimer F, Wang J, Lentsch V, Planas R, Jelcic I, et al. Memory B cells activate brain-homing, autoreactive $\mathrm{CD} 4+\mathrm{T}$ cells in multiple sclerosis. Cell. (2018) 175:85-100. doi: 10.1016/j.cell.2018.08.011

111. Harp CT, Ireland S, Davis LS, Remington G, Cassidy B, Cravens PD, et al. Memory B cells from a subset of treatment-naïve relapsing-remitting multiple sclerosis patients elicit CD4(+) T-cell proliferation and IFN- $\gamma$ 
production in response to myelin basic protein and myelin oligodendrocyte glycoprotein. Eur J Immunol. (2010) 40:2942-56. doi: 10.1002/eji.201 040516

112. Li R, Rezk A, Ghadiri M, Luessi F, Zipp F, Li H, et al. Dimethyl fumarate treatment mediates an anti-inflammatory shift in B cell subsets of patients with multiple sclerosis. J Immunol. (2017) 198:691698. doi: 10.4049/jimmunol.1601649

113. Duddy ME, Alter A, Bar-Or A. Distinct profiles of human B cell effector cytokines: a role in immune regulation? J Immunol. (2004) 172:342227. doi: 10.4049/jimmunol.172.6.3422

114. Duddy M, Niino M, Adatia F, Hebert S, Freedman M, Atkins H, et al. Distinct effector cytokine profiles of memory and naive human B cell subsets and implication in multiple sclerosis. J Immunol. (2007) 178:609299. doi: 10.4049/jimmunol.178.10.6092

115. Li R, Rezk A, Miyazaki Y, Hilgenberg E, Touil H, Shen P, et al. Proinflammatory GM-CSF-producing $B$ cells in multiple sclerosis and B cell depletion therapy. Sci Transl Med. (2015) 7:310. doi: 10.1126/scitranslmed.aab4176

116. Bar-Or A, Fawaz L, Fan B, Darlington PJ, Riegar A, Ghorayeb C, et al. Abnormal B-cell cytokine responses a trigger of T-cell-mediated disease in MS? Ann Neurol. (2010) 67:452-61. doi: 10.1002/ana.21939

117. Barr TA, Shen P, Brown S, Lampropoulou V, Roch T, Lawrie S, et al. B cell depletion therapy ameliorates autoimmune disease through ablation of IL-6-producing B cells. J Exp Med. (2012) 209:100110. doi: $10.1084 /$ jem. 20111675

118. Lisak RP, Benjamins JA, Nedelkoska L, Barger JL, Ragheb S, Fan B, et al. Secretory products of multiple sclerosis B cells are cytotoxic to oligodendroglia in vitro. J Neuroimmunol. (2012) 246:85-95. doi: 10.1016/j.jneuroim.2012.02.015

119. Lisak RP, Nedelkoska L, Benjamins JA, Schalk D, Bealmear B, Touil $\mathrm{H}$, et al. B cells from patients with multiple sclerosis induce cell death via apoptosis in neurons in vitro. J Neuroimmunol. (2017) 309:8899. doi: 10.1016/j.jneuroim.2017.05.004

120. Schuh E, Berer K, Mulazzani M, Feil K, Meinl I, Lahm H, et al. Features of human CD3+CD20+ T cells. J Immunol. (2016) 197:11117. doi: $10.4049 /$ jimmunol.1600089

121. Sabatino Jr. JJ, Wilson MR, Calabresi PA, Hauser SL, Schneck JP, Zamvil SS. Anti-CD20 therapy depletes activated myelin-specific CD8+ T cells in multiple sclerosis. Proc Natl Acad Sci USA. (2019) 116:2580007. doi: 10.1073/pnas.1915309116

122. von Essen MR, Ammitzbøll C, Hansen RH, Petersen ERS, McWilliam O, Marquart HV, et al. Proinflammatory CD20+ T cells in the pathogenesis of multiple sclerosis. Brain. (2019) 142:120-32. doi: 10.1093/brain/awy301

123. Gingele S, Skripuletz T, Jacobs R. Role of $\mathrm{CD} 20^{+} \mathrm{T}$ cells in multiple sclerosis: implications for treatment with ocrelizumab. Neural Regen Res. (2020) 15:663-64. doi: 10.4103/1673-5374.266913

124. Palanichamy A, Jahn S, Nickles D, Derstin M, Abounasr A, Hauser SL, et al. Rituximab efficiently depletes increased CD20-expressing $\mathrm{T}$ cells in multiple sclerosis patients. J Immunol. (2014) 193:58086. doi: 10.4049/jimmunol.1400118

125. Gingele S, Jacobus TL, Konen FF, Hümmert MW, Sühs K-W, Schwenkenbecher P, et al. Ocrelizumab depletes CD20? T cells in multiple sclerosis patients. Cells. (2018) 8:12. doi: 10.3390/cells8010012

126. Lock C, Hermans G, Pedotti R, Brendolan A, Schadt A, Garren H, et al. Gene-microarray analysis of multiple sclerosis lesions yields new targets validated in autoimmune encephalomyelitis. Nat Med. (2002) 8:50008. doi: $10.1038 / \mathrm{nm} 0502-500$

127. Constantinescu CS, Farooqi N, O’Brien K, Gran B. Experimental autoimmune encephalomyelitis (EAE) as a model for multiple sclerosis (MS). Br J Pharmacol. (2011) 164:1079-106. doi: 10.1111/j.1476-5381.2011.01302.x

128. Pöllinger B, Krishnamoorthy G, Berer K, Lassmann H, Bösl MR, Dunn $\mathrm{R}$, et al. Spontaneous relapsing-remitting EAE in the SJL/J mouse: MOGreactive transgenic T cells recruit endogenous MOG-specific B cells. J Exp Med. (2009) 206:1303-16. doi: 10.1084/jem.20090299

129. Gold R, Linington C, Lassmann H. Understanding pathogenesis and therapy of multiple sclerosis via animal models: 70 years of merits and culprits in experimental autoimmune encephalomyelitis research. Brain. (2006) 129:1953-71. doi: 10.1093/brain/awl075
130. Bradl M, Lassmann H. Neurologic autoimmunity. Handb Clin Neurol. (2016) 133:121-43.

131. Simmons SB, Pierson ER, Lee SY, Goverman JM. Modeling the heterogeneity of multiple sclerosis in animals. Trends Immunol. (2013) 34:41022. doi: 10.1016/j.it.2013.04.006

132. Peters A, Pitcher LA, Sullivan JM, Mitsdoerffer M, Acton SE, Franz B, et al. Th17 cells induce ectopic lymphoid follicles in central nervous system tissue inflammation. Immunity. (2011) 35:986-96. doi: 10.1016/j.immuni.2011.10.015

133. Kuerten S, Lichtenegger FS, Faas S, Angelov DN, Tary-Lehmann M, Lehmann PV. MBP-PLP fusion protein-induced EAE in C57BL/6 mice. $J$ Neuroimmunol. (2006) 177:99-111. doi: 10.1016/j.jneuroim.2006.03.021

134. Hundgeburth LC, Wunsch M, Rovituso D, Recks MS, Addicks K, Lehmann $\mathrm{PV}$, et al. The complement system contributes to the pathology of experimental autoimmune encephalomyelitis by triggering demyelination and modifying the antigen-specific $\mathrm{T}$ and $\mathrm{B}$ cell response. Clin Immunol. (2013) 146:155-64. doi: 10.1016/j.clim.2012.12.007

135. Kuerten S, Pauly R, Rottlaender A, Rodi M, Gruppe TL, Addicks $\mathrm{K}$, et al. Myelin-reactive antibodies mediate the pathology of MBPPLP fusion protein MP4-induced EAE. Clin Immunol. (2011) 140:5462. doi: 10.1016/j.clim.2011.03.009

136. Kuerten S, Javeri S, Tary-Lehmann M, Lehmann PV, Angelov DN. Fundamental differences in the dynamics of CNS lesion development and composition in MP4- and MOG peptide 35-55-induced experimental autoimmune encephalomyelitis. Clin Immunol. (2008) 129:256-67. doi: 10.1016/j.clim.2008.07.016

137. Kuerten S, Schickel A, Kerkloh C, Recks MS, Addicks K, Ruddle, NH, et al. Tertiary lymphoid organ development coincides with determinant spreading of the myelin-specific T cell response. Acta Neuropathol. (2012) 124:861-73. doi: 10.1007/s00401-012-1023-3

138. Batoulis H, Wunsch M, Birkenheier J, Rottlaender A, Gorboulev V, Kuerten S. Central nervous system infiltrates are characterized by features of ongoing B cell-related immune activity in MP4-induced experimental autoimmune encephalomyelitis. Clin Immunol. (2015) 158:4758. doi: 10.1016/j.clim.2015.03.009

139. Pierce SK, Morris JF, Grusby MJ, Kaumaya P, van Buskirk A, Srinivasan M, et al. Antigen-presenting function of B lymphocytes. Immunol Rev. (1988) 106:149-80. doi: 10.1111/j.1600-065x.1988.tb00778.x

140. Weber MS, Prod'homme T, Patarroyo JC, Molnarfi N, Karnezis T, Lehmann-Horn K, et al. B-cell activation influences T-cell polarization and outcome of anti-CD20 B-cell depletion in central nervous system autoimmunity: B cells in CNS autoimmunity. Ann Neurol. (2010) 68:36983. doi: 10.1002/ana.22081

141. Harp CR, Archambault AS, Sim J, Shlomchik MJ, Russell JH, Gregory FW. B cells are capable of independently eliciting rapid reactivation of encephalitogenic CD4 T cells in a murine model of multiple sclerosis. PLoS ONE. (2018) 13:e0199694. doi: 10.1371/journal.pone.0199694

142. Molnarfi N, Schulze-Topphoff U, Martin MS, Patarroyo JS, Prod'homme T, Varrin-Doyer M, et al. MHC class II-dependent B cell APC function is required for induction of CNS autoimmunity independent of myelin-specific antibodies. J Exp Med. (2013) 210:2921-37. doi: 10.1084/jem.20130699

143. Shen P, Roch T, Lampropoulou V, O'Connor RA, Stervbo U, Hilgenberg E, et al. IL-35-producing B cells are critical regulators of immunity during autoimmune and infectious diseases. Nature. (2014) 507:36670. doi: 10.1038/nature12979

144. Matsushita T, Yanaba K, Bouaziz J-D, Fujimoto M, Tedder TF. Regulatory $B$ cells inhibit EAE initiation in mice while other B cells promote disease progression. J Clin Invest. (2008) 118:3420-30. doi: 10.1172/JCI36030

145. Häusler D, Häusser-Kinzel S, Feldmann L, Torke S, Lepennetier G, Bernard CCA, et al. Functional characterization of reappearing B cells after antiCD20 treatment of CNS autoimmune disease. Proc Natl Acad Sci USA. (2018) 115:9773-78. doi: 10.1073/pnas.1810470115

146. Chen W-W, Zhang X, Huang W-J. Role of neuroinflammation in neurodegenerative diseases. Mol Med Rep. (2016) 13:339196. doi: 10.3892/mmr.2016.4948

147. More SV, Kumar H, Kim IS, Song SY, Choi DK. Cellular and molecular mediators of neuroinflammation in the pathogenesis of Parkinson's disease. Mediators Inflamm. (2013) 2013:952375. doi: 10.1155/2013/952375 
148. Chaplin DD. Overview of the immune response. J Allergy Clin Immunol. (2010) 125:S3-23. doi: 10.1016/j.jaci.2009.12.980

149. Dörner T, Radbruch A. Antibodies and B cell memory in viral Immunity. Immunity. (2007) 27:384-92. doi: 10.1016/j.immuni.2007.09.002

150. Zinkernagel RM. Immunology taught by viruses. Science. (1996) 271:17378. doi: 10.1126/science.271.5246.173

151. Cyster JG, Allen CDC. B cell responses: cell interaction dynamics and decisions. Cell. (2019) 177:524-40. doi: 10.1016/j.cell.2019.03.016

152. Swanson II PA, McGavern DB. Viral diseases of the central nervous system. Curr Opin Virol. (2015) 11:44-54. doi: 10.1016/j.coviro.2014.12.009

153. Abid FB, Abukhattab M, Ghazouani H, Khalil O, Gohar A, Soub AH, et al. Epidemiology and clinical outcomes of viral central nervous system infections. Int J Infect Dis. (2018) 73:85-90. doi: 10.1016/j.ijid.2018.06.008

154. Kennedy PGE. Viral encephalitis causes, differential diagnosis and management. J Neurol Neurosurg Psychiatry. (2004) 75:100-15. doi: 10.1136/jnnp.2003.034280

155. Jelcic I, Jelcic I, Faigle W, Sospedra M, Martin R. Immunology of progressive multifocal leukoencephalopathy. J Neurovirol. (2015) 21:61422. doi: 10.1007/s13365-014-0294-y

156. Kleinschmidt-DeMasters BK, Tyler KL. Progressive multifocal leukoencephalopathy complicating treatment with Natalizumab and interferon beta-1a for multiple sclerosis. $N$ Engl J Med. (2005) 353:369-74. doi: 10.1056/NEJMoa051782

157. Durali D, de Goër de Herve M-G, Gasnault J, Taoufik Y. B cells and progressive multifocal leukoencephalopathy: search for the missing link. Front Immunol. (2015) 6:241. doi: 10.3389/fimmu.2015. 00241

158. Focosi D, Tuccori M, Maggi F. Progressive multifocal leukoencephalopathy and anti-CD20 monoclonal antibodies: what do we know after 20 years of rituximab. Rev Med Virol. (2019) 29:e2077. doi: 10.1002/rmv.2077

159. Ramakrishna C, Stohlman SA, Atkinson RD, Shlomchik MJ, Bergmann CC. Mechanisms of central nervous system viral persistence: the critical role of antibody and B cells. J Immunol. (2002) 168:1204-11. doi: 10.4049/jimmunol.168.3.1204

160. Priyamvada L, Suthar MS, Ahmed R, Wrammert J. Humoral immune responses against zika virus infection and the importance of preexisting flavivirus immunity. J Infect Dis. (2017) 216:90611. doi: 10.1093/infdis/jix513

161. Smith-Norowitz TA, Sobel RA, Mokhtarian F. B cells and antibodies in the pathogenesis of myelin injury in semliki forest virus encephalomyelitis. Cell Immunol. (2000) 200:27-35. doi: 10.1006/cimm.2000.1613

162. Mutnal MB, Hu S, Schachtele SJ, Lokensgard JR. Infiltrating regulatory B cells control neuroinflammation following viral brain infection. J Immunol. (2014) 193:6070-80. doi: 10.4049/jimmunol.1400654

163. Hooper DC, Phares TW, Fabis MJ, Roy R. The production of antibody by invading B cells is required for the clearance of rabies virus from the central nervous system. PLoS Negl Trop Dis. (2009) 3:e535. doi: 10.1371/journal.pntd.0000535

164. Diamond MS, Shrestha B, Marri A, Mahan D, Engle MB. Cells and antibody play critical roles in the immediate defense of disseminated infection by west nile encephalitis virus. J Virol. (2003) 77:257886. doi: 10.1128/JVI.77.4.2578-2586.2003

165. Tschen S-I, Stohlman SA, Ramakrishna C, Hinton DR, Atkinson RD, Bergmann CC. CNS viral infection diverts homing of antibody-secreting cells from lymphoid organs to the CNS. Eur J Immunol. (2006) 36:60312. doi: 10.1002/eji.200535123

166. Marques CP, Kapil P, Hinton DR, Hindiger C, Nutt SL, Ransohoff $\mathrm{RM}$, et al. CXCR3-dependent plasma blast migration to the central nervous system during viral encephalomyelitis. J Virol. (2011) 85:613647. doi: 10.1128/jvi.00202-11

167. Metcalf TU, Baxter VK, Nilaratanakul V, Griffin DE. Recruitment and retention of $\mathrm{B}$ cells in the central nervous system in response to alphavirus encephalomyelitis. J Virol. (2013) 87:2420-9. doi: 10.1128/JVI. 01769-12

168. Lokensgard JR, Mutnal MB, Prasad S, Sheng W, Hu S. Glial cell activation, recruitment, and survival of B-lineage cells following MCMV brain infection. J Neuroinflammation. (2016) 13, 114. doi: 10.1186/s12974-0160582-y
169. Klein RS, Garber C, Funk KE, Salimi H, Soung A, Kanmongue M, et al. Neuroinflammation during RNA viral infections. Annu Rev Immunol. (2019) 37:73-95. doi: 10.1146/annurev-immunol-042718-041417

170. Phares TW, DiSano KD, Stohlman SA, Segal BM, Bergmann CC. CXCL13 promotes isotype-switched B cell accumulation to the central nervous system during viral encephalomyelitis. Brain Behav Immun. (2016) 54:12839. doi: 10.1016/j.bbi.2016.01.016

171. Phares TW, Marques CP, Stohlman SA, Hinton DR, Bergmann CC. Factors supporting intrathecal humoral responses following viral encephalomyelitis. J Virol. (2011) 85:2589-98. doi: 10.1128/JVI.02260-10

172. Chastain EML, Miller SD. Theiler's murine encephalomyelitis virusinduced demyelinating disease (TMEV-IDD) and autoimmunity. Infection Autoimmunity. In: Shoenfeld Y, Agmon-Levin N, Rose NR, editors. Infection and Autoimmunity (Second Edition). San Diego, CA: Elsevier (2015). p. 465-76. doi: 10.1016/B978-0-444-63269-2.00023-4

173. DiSano KD, Royce DB, Gilli F, Pachner AR. Central nervous system inflammatory aggregates in the Theiler's virus model of progressive multiple sclerosis. Front Immunol. (2019) 10:1821. doi: 10.3389/fimmu.2019.01821

174. DiSano KD, Stohlman SA, Bergmann CC. Activated GL7+ B cells are maintained within the inflamed CNS in the absence of follicle formation during viral encephalomyelitis. Brain Behav Immun. (2017) 60:71-83. doi: 10.1016/j.bbi.2016.09.022

175. Virtanen JO, Jacobson S. Viruses and multiple sclerosis. CNS Neurol Disord Drug Targets. (2012) 11:528-44. doi: 10.2174/187152712801661220

176. Hassani A, Corboy JR, Al-Salam S, Khan G. Epstein-Barr virus is present in the brain of most cases of multiple sclerosis and may engage more than just B cells. PLoS ONE. (2018) 13:e0192109. doi: 10.1371/journal.pone.0192109

177. Ascherio A, Munger KL. Epstein-barr virus infection and multiple sclerosis: a review. J Neuroimmune Pharmacol. (2010) 5:271-7. doi: 10.1007/s11481-010-9201-3

178. Polepole P, Bartenslager A, Liu Y, Petro TM, Fernando S, Zhang L. Epstein Barr virus-immortalized B lymphocytes exacerbate experimental autoimmune encephalomyelitis in xenograft mice. $J$ Med Virol. (2020) doi: 10.1002/jmv.26188. [Epub ahead of print].

179. Morandi E, Jagessar SA, 't Hart BA, Gran B. EBV Infection empowers human B cells for autoimmunity: role of autophagy and relevance to multiple sclerosis. J Immunol. (2017) 199:435-48. doi: 10.4049/jimmunol.1700178

180. Serafini B, Rosicarelli B, Franciotta D, Magliozzi R, Reynolds R, Cinque P, et al. Dysregulated Epstein-Barr virus infection in the multiple sclerosis brain. J Exp Med. (2007) 204:2899-912. doi: 10.1084/jem.20071030

181. Veroni C, Serafini B, Rosicarelli B, Fagnani C, Aloisi F. Transcriptional profile and Epstein-Barr virus infection status of laser-cut immune infiltrates from the brain of patients with progressive multiple sclerosis. $J$ Neuroinflammation. (2018) 15:18. doi: 10.1186/s12974-017-1049-5

182. Pender MP. The essential role of Epstein-Barr virus in the pathogenesis of multiple sclerosis. Neuroscientist. (2011) 17:351-67. doi: 10.1177/1073858410381531

183. Bar-Or A, Pender MP, Khanna R, Steinman L, Hartung HP, Maniar T, et al. Epstein-barr virus in multiple sclerosis: theory and emerging immunotherapies. Trends Mol Med. (2020) 26:296-310. doi: 10.1016/j.molmed.2019.11.003

184. Ong LTC, Parnell GP, Afrasiabi A, Stewart GJ, Swaminathan S, Booth DR. Transcribed B lymphocyte genes and multiple sclerosis risk genes are underrepresented in Epstein-Barr Virus hypomethylated regions. Genes Immun. (2020) 21:91-9. doi: 10.1038/s41435-019-0089-5

185. Moreno MA, Or-Geva N, Aftab BT, Khanna R, Croze E, Steinman L, et al. Molecular signature of Epstein-Barr virus infection in MS brain lesions. Neurol Neuroimmunol Neuroinflamm. (2018) 5:e466. doi: 10.1212/NXI.0000000000000466

186. Serafini B, Severa M, Columba-Cabezas S, Rosicarelli B, Veroni C, Chiapetta $\mathrm{G}$, et al. Epstein-Barr virus latent infection and BAFF expression in B cells in the multiple sclerosis brain: implications for viral persistence and intrathecal B-cell activation. J Neuropathol Exp Neurol. (2010) 69:67793. doi: 10.1097/NEN.0b013e3181e332ec

187. Morandi E, Tanasescu R, Tarlinton RE, Constantin-Teodosiu D, Gran B. Do antiretroviral drugs protect from multiple sclerosis by inhibiting expression of MS-associated retrovirus?. Front Immunol. (2019) 9:3092. doi: 10.3389/fimmu.2018.03092 
188. Mameli G, Poddighe L, Mei A, Uleri E, Sotgiu S, Serra C, et al. Expression and activation by Epstein Barr virus of human endogenous retroviruses- $W$ in blood cells and astrocytes: inference for multiple sclerosis. PLoS ONE. (2012) 7:e44991. doi: 10.1371/journal.pone.0044991

189. Peferoen LAN, Lamers F, Lodder LNR, Gerritsen WH, Huitinga I, Melief J, et al. Epstein Barr virus is not a characteristic feature in the central nervous system in established multiple sclerosis. Brain. (2010) 133:e137. doi: 10.1093/brain/awp296

190. Ramesh A, Schubert RD, Greenfield AL, Dandekar R, Loudermilk R, Sabatino JJ Jr, et al. A pathogenic and clonally expanded B cell transcriptome in active multiple sclerosis. Proc Natl Acad Sci USA. (2020) 117:2293243. doi: 10.1073/pnas. 2008523117

191. Huygens A, Dauby N, Vermijlen D, Marchant A. Immunity to cytomegalovirus in early life. Front Immunol. (2014) 5:552. doi: 10.3389/fimmu.2014.00552

192. Cannon MJ, Schmid DS, Hyde TB. Review of cytomegalovirus seroprevalence and demographic characteristics associated with infection. Rev Med Virol. (2010) 20:202-13. doi: 10.1002/rmv.655

193. Langer-Gould A, Wu J, Lucas R, Smith J, Gonzales E, Amezcua $\mathrm{L}$, et al. Epstein-Barr virus, cytomegalovirus, and multiple sclerosis susceptibility: a multiethnic study. Neurology. (2017) 89:1330-37. doi: 10.1212/WNL.0000000000004412

194. Vanheusden M, Broux B, Welten SPM, Peeters LM, Panagoti E, Wijmeersch BV, et al. Cytomegalovirus infection exacerbates autoimmune mediated neuroinflammation. Sci Rep. (2017) 7:663. doi: 10.1038/s41598-017-00645-3

195. Halenius A, Hengel H. Human cytomegalovirus and autoimmune disease. Biomed Res Int. (2014) 2014:472978. doi: 10.1155/2014/472978

196. Sundqvist E, Bergström T, Daialhosein H, Nyström M, Sundström P, Hillert J, et al. Cytomegalovirus seropositivity is negatively associated with multiple sclerosis. Mult Scler. (2014) 20:165-73. doi: 10.1177/1352458513494489

197. Maple PAC, Tanasescu R, Gran B, Constantinescu CS. The different responses to cytomegalovirus (CMV) Epstein-Barr virus (EBV) infection in UK people with multiple sclerosis (PwMS) compared to controls. J Infect. (2020) 80:320-25. doi: 10.1016/j.jinf.2019.10.017

198. Zabalza A, Vera A, Alari-Pahissa E, Munteis E, Moreira A, Yélamos J, et al. Impact of cytomegalovirus infection on B cell differentiation and cytokine production in multiple sclerosis. J Neuroinflammation. (2020) 17:161. doi: 10.1186/s12974-020-01840-2

199. Das A, Ellis G, Pallant C, Lopes AR, Khanna P, Peppa D, et al. IL-10producing regulatory $\mathrm{B}$ cells in the pathogenesis of chronic hepatitis $\mathrm{B}$ virus infection. J Immunol. (2012) 189:3925-35. doi: 10.4049/jimmunol.1103139

200. Kakalacheva K, Münz C, Lünemann JD. Viral triggers of multiple sclerosis. Biochim Biophys Acta. (2011) 1812:132-40. doi: 10.1016/j.bbadis.2010. 06.012

201. Corcione A, Casazza S, Ferretti E, Giunti D, Zappia E, Pistorio A, et al. Recapitulation of $\mathrm{B}$ cell differentiation in the central nervous system of patients with multiple sclerosis. Proc Natl Acad Sci USA. (2004) 101:1106469. doi: 10.1073/pnas.0402455101

202. Meinl E, Krumbholz M. Hohlfeld R. B lineage cells in the inflammatory central nervous system environment: migration, maintenance, local antibody production, and therapeutic modulation. Ann Neurol. (2006) 59:88092. doi: 10.1002/ana.20890

203. Agahozo MC, Peferoen L, Baker D, Amor, S. CD20 Therapies in multiple sclerosis and experimental autoimmune encephalomyelitistargeting $\mathrm{T}$ or B cells? Mult Scler Relat Disord. (2016) 9:110-17. doi: 10.1016/j.msard.2016.07.011

204. Kooi E-J, Geurts JJG, van Horssen J, Bø L, van der Valk P. Meningeal inflammation is not associated with cortical demyelination in chronic multiple sclerosis. J Neuropathol Exp Neurol. (2009) 68:1021-28. doi: 10.1097/NEN.0b013e3181b4bf8f

205. Rothstein TL, Griffin DO, Holodick NE, Quach TD, Kaku H. Human B-1 cells take the stage. Ann N Y Acad Sci. (2013) 1285:97-114. doi: 10.1111/nyas. 12137

206. Mauri C, Menon M. The expanding family of regulatory B cells. Int Immunol. (2015) 27:479-86. doi: 10.1093/intimm/dxv038

207. Peng B, Ming Y, Yang C. Regulatory B cells: the cutting edge of immune tolerance in kidney transplantation. Cell Death Dis. (2018) 9:1-13. doi: 10.1038/s41419-017-0152-y

208. Yanaba K, Bouaziz J-D, Haas KM, Poe JC, Fujimoto M, Tedder TF. A regulatory $\mathrm{B}$ cell subset with a unique CD1dhiCD5+ phenotype controls $\mathrm{T}$ cell-dependent inflammatory responses. Immunity. (2008) 28:63950. doi: 10.1016/j.immuni.2008.03.017

209. Bittner S, Ruck T, Wiendl H, Grauer OM, Meuth SG. Targeting B cells in relapsing-remitting multiple sclerosis: from pathophysiology to optimal clinical management. Ther Adv Neurol Disord. (2017) 10:5166. doi: $10.1177 / 1756285616666741$

210. Zhang N, Bevan MJ. CD8+ T cells: foot soldiers of the immune system. Immunity. (2011) 35:161-68. doi: 10.1016/j.immuni.2011.07.010

211. Friese MA, Fugger L. Autoreactive CD8+ T cells in multiple sclerosis: a new target for therapy? Brain. (2005) 128:1747-763. doi: 10.1093/brain/awh578

Conflict of Interest: The authors declare that the research was conducted in the absence of any commercial or financial relationships that could be construed as a potential conflict of interest.

Copyright (C) 2020 Chunder, Schropp and Kuerten. This is an open-access article distributed under the terms of the Creative Commons Attribution License (CC BY). The use, distribution or reproduction in other forums is permitted, provided the original author(s) and the copyright owner(s) are credited and that the original publication in this journal is cited, in accordance with accepted academic practice. No use, distribution or reproduction is permitted which does not comply with these terms. 